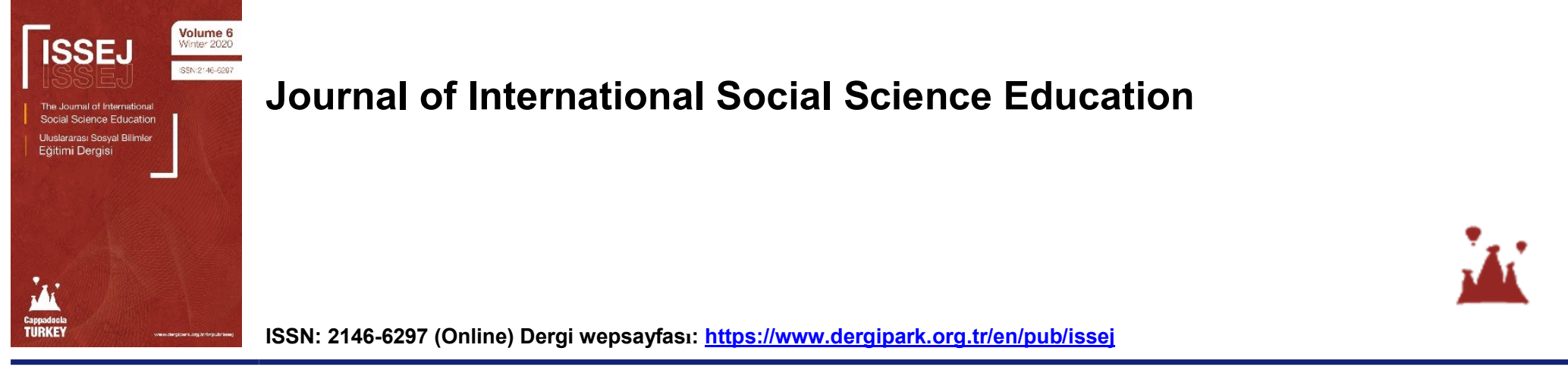

Sosyal Bilgiler Öğretmen Adaylarının Kadına Yönelik Şiddet Tutumlarının İncelenmesi

Serkan Keleşoğlu

Yasemin Esen

Önerilen atıf: Keleşoğlu, S. \& Esen, Y. (2020). Sosyal bilgiler öğretmen adaylarının kadına yönelik şiddet tutumlarının incelenmesi, Uluslararası Sosyal Bilimler Eğitimi Dergisi, 6(2), 273-298. DOI: $10.47615 /$ issej. 826164 .

Makale linki: https://doi.org/10.47615/issej.826164 @ 2020 Yazar(lar). Baskınlar ve izinler:
USBED/Uluslararası Sosyal Bilimler Eğitimi
Dergisi

USBED/Ulụslararası Sosyal Bilimler Eğitimi Dergisi hakemli bir çevrimiçi dergidir. Bu makale araştırma, ögretim ve özel çalışmalar macıyla küllanılabilir. Makălenin iç̧eriğinden yanlızca yazarlar sorumludur Dergi makalelerin telif hakkına sahiptir. Yayıncı, araştırma materyalinin kullanımıyla bağlantılı veya dogrudan veya dolaylı olarak ortaya çıkan herhangi bir kayıp, işlem, talep veya masraf veya zarardan sorumlu tutulamaz. 


\title{
Sosyal bilgiler öğretmen adaylarının kadına yönelik şiddet tutumlarının incelenmesi
}

\author{
Serkan Keleşoğlu (1) Yasemin Esen \\ Eğitim Bilimleri Fakültesi, Ankara Üniversitesi, Ankara, 06590, Türkiye
}

ÖZ

Kadına yönelik şiddet küresel çapta en önemli insan hakları ihlallerinden biridir. Tarihsel süreç içerisinde özellikle ataerki toplumlarda kadın hep ikinci sınıf insan olarak görülmüş ve üzerinde güç kullanılarak kontrol altında tutulmaya

çalışılmıştır. Bu kontrol etme davranışının bir yansıması olarak kadınlar, sırf cinsiyetlerinden dolayı, fiziksel şiddet başta olmak üzere, diğer şiddet biçimlerine (cinsel, psikolojik ve ekonomik şiddet) maruz kalmışlar, kişi hak ve özgürlüklerinden mahrum bırakılmışlardır. Her ne kadar uluslararası alanda çeşitli belgeler ile kadına yönelik şiddet önlenmek istense de henüz beklenen sonuca ulaşılamamış ve yapılan düzenlemeler birçok ülkede kâğıt üstünde kalmıştır. Bu çalışma kadına yönelik şiddetin önlenmesinde önemli görevlerden birini üstlenebilecek bir meslek grubu olarak öğretmenlerin hizmet öncesinde kadına yönelik siddet tutumlarını ve bu tutumları etkileyen değişkenleri belirlemeyi amaçlamıştır. Araştırmanın çalışma grubunu altı devlet üniversitesinde öğrenim gören sosyal bilgiler öğretmen adayları oluştưrmaktadır. Çalışma grubundan "Kadına Yönelik Şiddet Tutum Ölçeği” aracılığıyla veri toplanmıştır. Araştırma sonuçlarına göre kadına yönelik şiddet tutumunun cinsiyet, anne-baba eğitim durumu, romantik bir ilişki yaşamış olma, romantik bir ilişki yaşıyor olma durumuna göre farklılaştığı bulunmuştur. Araştırma sonuçlarına dayalı olarak; hedef kitlesi erkek olan çalışmaların planlanması ve yaşama geçirilmesi, annelere ve babalara yönelik eğitimler düzenlenmesi, kişiler arasında etkili ve sağlıklı iletişim kurulabilmesi için uygun ortamlar hazırlanması ve çalışmanın farklı gruplarla tekrar edilmesi önerilmektedir.
MAKALE TARİHI

Geliș tarihi 15 Kasım 2020

Kabul tarihi 17 Aralık 2020

Yayım tarihi 31 Aralık 2020

ANAHTAR KELIMER

Kadına Yönelik Şiddet

Tutumu,

Sosyal Bilgiler Öğretmen

Eğitimi.

Makale Türü

Araștırma makalesi

ILETișiM Serkan Keleşoğlu @ skelesoglu@ankara.edu.tr

(C) 2020 Serkan Keleşoğlu, Yasemin Esen

This is an Open Access article distributed under the terms of the Creative Commons Attribution-NonCommercial-NoDerivatives License (http://creativecommons.org/licenses/by-nc-nd/4.0/), which permits non-commercial re-use, distribution, and reproduction in any medium, provided the original work is properly cited, and is not altered, transformed, or built upon in any way. 


\section{Investigation of social studies pre-service teachers' attitudes towards violence against women}

\section{Serkan Keleşoğlu (i) Yasemin Esen}

Eğitim Bilimleri Fakültesi, Ankara Üniversitesi, Ankara, 06590, Türkiye

\begin{abstract}
Violence against women is a major global problem that both in Turkey and around the world. This problem is seen both as a health problem and as a human rights issue. Especially in patriarchal societies, women have always been regarded as second-class people and have been tried to be controlled by force. As a reflection of this controlling behavior, women were exposed to other forms of violence (sexual, psychological and economic), mainly physical violence, because they were women, and were deprived of their rights and freedoms. Despite the desire to intervene with violence against women with various documents on the international area, the expected success has not yet been achieved and the regulations have remained on paper in many countries. This study aimed to determine the preservice teachers' attitudes of violence towards women and the variables affecting these attitudes of women as a group of professions that can take one of the important duties in preventing violence against women. The study group of the research is social studies pre-service teachers who were studying at six state universities. Data on the research were collected from the study group by the "Attitude Scale for Violence Against Women". According to the results, there were significant differences between the attitudes towards violence towards women and gender, parental education status, having romantic relationship and maintain a romantic relationship. Based on the results of the research; It is suggested that appropriate mass media should be prepared for effective and healthy communication among the people and the work should be repeated with different groups.
\end{abstract}

ARTICLE HISTORY

Received 15 November 2020

Accepted 17 December 2020

Published 31 December 2020

\section{KEYWORDS}

Violence Against Women, Social Studies Teacher

Education,

Attitudes.

Type of the Paper

Research article

\section{Giriș}

Kadınlara yönelik şiddet, küresel bağlamda en yaygın sorunlardan biri olmaya devam etmektedir. Türkiye ise şiddet yelpazesinin en uç noktası olarak tanımlanan kadın cinayetlerinin artan oranlarıyla her gün yüzleşen bir ülke haline gelmiş durumdadır. Kadınlar, son yıllarda, belki de diğer haklarından daha fazla, yaşam hakları için endişe duyar hale gelmişlerdir. 
Türkiye'nin 2011 tarihinde imzaladığı Kadinlara Yönelik Şiddet ve Ev içi Şiddetin Önlenmesi ve Bunlarla Mücadeleye Dair Avrupa Konseyi Sözleşmesi (İstanbul Sözleşmesi) ile 6284 sayll Ailenin Korunması ve Kadina Karşı Şiddetin Önlenmesine Dair Kanun düzenlemesi, kadına yönelik șiddetle mücadele konusunda olumlu değişiklikler getirmiş olsa da yasal düzenlemelerin kadına yönelik şiddetin önlenmesi konusunda sınırlı bir ilerleme sağladığı görülmektedir. Başka bir ifadeyle, kadına yönelik şiddetle mücadelede yasal düzenlemelerin tek başına yeterli olmadığı, diğer toplumsal kurumların da bu mücadelede sorumluluk ve inisiyatif kullanması gerektiği açıktır. Kadına yönelik şiddetin bir insan hakları meselesi olarak kabul edilmesi, bu konunun bütüncül bir yaklaşımla ve tüm sektörlerin (özel ve kamu) iş birliği ile ele alınmasını gerektirmektedir. Böyle bir yaklaşım çerçevesinde paydaşlar arasındaki eşgüdümü ve iş birliğini sağlayan ana kurum olan Aile, Çalışma ve Sosyal Hizmetler Bakanlığı'nın Kadına Yönelik Şiddetle Mücadele Projesi Ulusal Eylem Planları (2007-2010 ve 2012-2015), Türkiye'nin uluslararası taahhütleri çerçevesinde belirlediği hedeflere ulaşabilmede, üniversitelere ve öğretmen yetiştiren fakültelere de sorumluluk yüklemektedir. $\mathrm{Bu}$ sorumluluk çerçevesinde gerçekleştirilen bu araştırma, kadına yönelik şiddetin önlenmesinde önemli görevlerden birini üstlenebilecek bir meslek grubu olarak öğretmen adaylarının kadına yönelik şiddet tutumlarını ve bu tutumları etkileyen değişkenleri belirlemeyi amaçlamaktadır.

Kadına yönelik şiddetin boyutlarını ortaya koyacak çalışmaların yapılması, konuya uluslararası düzeyde dikkat çekilmesi ve kadına yönelik şiddetin bir insan hakkı ihlali olarak kabul edilmesi uzun yıllar almıştır. 1970'li yıllardan başlayarak ulusal ve uluslararası ölçekteki kadın hareketinin ve sivil toplum örgütlerinin çabaları sayesinde; günümüzde kadınların ve kız çocukların maruz kaldığı şiddetin ve ayrımcılığın bir insan hakları ihlali olduğu ve toplumsal kalkınmanın önünde büyük bir engel oluşturduğu kabul edilmiştir. 1980 yılında Kopenhag'da toplanan 2. Dünya Kadın Konferansı sonuç bildirgesinde kadınların ve çocukların şiddetten korunmasına yapılan vurgu, 1985 yılında Nairobi'de gerçekleştirilen 3. Kadın Konferansı İleriye Yönelik Stratejiler Belgesi'nde kadına yönelik şiddet konusunda devletlere yasal ve politik önlemler almaları çağrısıyla farklı bir boyut kazanmıştır. Bu süreç, kadınlara ve kız çocuklara yönelik şiddetin, kadın hakları ile ilgili bütün uluslararası belgelerde yer almasını sağlamış; kadına yönelik şiddete büyüteç tutarak, küresel ölçekte mücadele edilmesi gereken yaygın ve önemli bir toplumsal sorun olarak belirlemiştir. Böylece, aile mahremiyeti mitine hapsedilerek görünmez kılınan kadına yönelik şiddet, artık kamusal ve politik bir mesele haline gelmiştir.

Birleşmiş Milletler Kadınlara Karşı Her Türlü Ayrımcılı̆̆ın Önlenmesi Komitesi (CEDAW Komitesi), 19 No'lu Tavsiye Kararı'nda (1992) kadınlara yönelik toplumsal cinsiyete dayalı şiddet, "bir kadına sırf kadın olduğu için yöneltilen ya da orantısız bir şekilde kadınları etkileyen şiddet" olarak tanımlanmış ve cinsiyete dayalı bir ayrımcılık olduğu belirtilmiștir. 1993'te kabul edilen BM Kadınlara Karşı Şiddetin Ortadan Kaldırılması Bildirgesi'nin önsözünde ise kadınlara yönelik şiddet, "erkekler ve kadınlar arasındaki eşitlikçi olmayan güç iliş̧kilerinin tarihsel bir göstergesi" ve "erkeklerle karşılaştırıldığında kadınları zorla bağımlı bir konuma sokmanın çok önemli toplumsal mekanizmalarından biri" olarak tanımlamıştır. Bildirgede kadınlara yönelik şiddet hem kamusal hem de özel yaşam çerçevesinde ele alınmış ve bu olgunun kadınların ilerlemesinin önündeki en büyük engellerden biri olduğu belirtilmiştir. 1995 yılında Pekin'de düzenlenen Dördüncü Kadın Konferansı'nda (Pekin Deklarasyonu ve Eylem Platformu, 1995), devletlerin sorumluluğu olarak tanımlanan kadınlara yönelik şiddetin ortadan kaldırılmasının, ülkelerin demokrasi, kalkınma ve barış hedeflerine ulaşabilmeleri için alınması gereken acil tedbirlerden biri olduğu vurgulanmıştır. Kadınlara karşı şiddetin tanımı, kapsamı ve türleri bağlamında en güncel belge olan Kadınlara Yönelik Şiddet ve Aile İçi Şiddetin Önlenmesi ve Bunlarla Mücadeleye ilişkin Avrupa Konseyi Sözleşmesi (İstanbul Sözleşmesi), 2011 yılında İstanbul'da imzaya açılmış ve ilk imza atan ülke de Türkiye olmuştur. İstanbul Sözleşmesi'nin 3. maddesinde (2014) kadına yönelik şiddet; 
"Bir insan hakları ihlali ve kadınlara yönelik ayrımcılığın bir biçimi olarak anlaşılmaktadır ve ister kamusal ister özel alanda meydana gelsin, kadınlara fiziksel, cinsel, psikolojik veya ekonomik zarar veya 1stırap veren veya verebilecek olan toplumsal cinsiyete dayalı her türlü eylem ve bu eylemlerle tehdit etme, zorlama veya keyfi olarak özgürlükten yoksun bırakma” biçiminde tanımlanmıştır.

İstanbul Sözleşmesi'nde, kadınlara karşı şiddet teriminin, toplumsal cinsiyete dayalı tüm şiddet eylemlerini kapsadığı, kadınların ve kız çocukların toplumsal cinsiyete dayalı şiddete maruz kalma riskinin erkeklerden daha yüksek olduğu, aile içi şiddetin kadınları orantısız şekilde etkilediği, çocukların aile içindeki şiddete tanık olmak dâhil, şiddetin mağduru oldukları belirtilmektedir.

Avrupa Birliği Temel Haklar Ajansı'nın üye ülkelerden 42.000 kadının katılımı ile gerçekleştirdiği araştırmaya göre; her üç kadından biri 15 yaşından itibaren fiziksel ya da cinsel şiddete maruz kalmaktadır. Kadınların yaklaşık \%12'si 15 yaşından önce yetişkin birinin tacizine uğramıştır. Yine bu araştırmada, kadınların yaygın biçimde şiddete maruz kaldıkları ancak bunların çok az bir bölümünün kayıtlara geçtiği, şiddet nedeniyle ilişkisini sonlandıran kadınların halen risk altında oldukları ve her beş kadından ikisinin şimdiki ya da eski eşinden psikolojik şiddet gördüğü sonuçlarına ulaşılmıştır (Akt: Kadının Statüsü Genel Müdürlügüü, 2016). Türkiye'de ise Şubat 2010 ile Ağustos 2011 dönemleri arasındaki resmi kayıtlara göre ülke çapında 78.500 aile içi şiddet vakası yaşanmıştır (Köknel, 2013). Hacettepe Üniversitesi Nüfus Etütleri Enstitüsü tarafından gerçekleştirilen ve bu konudaki en geniş kapsamlı araştırma olan Türkiye'de Kadına Yönelik Aile İçi Şiddet Araştırması (2015) verilerine göre, Türkiye'de her 10 kadından yaklaşık 4'ü eşinin ya da birlikte olduğu erkeğin fiziksel şiddetine maruz kalmış, \%12'si cinsel şiddet, \%44'ü duygusal şiddet/istismar, \%30’u ekonomik şiddet/istismar görmüştür. Bu araştırmada, İstanbul Sözleşmesi'nin şiddet tanımı bağlamında önemli konular olan çocukluk döneminde cinsel taciz, erken evlilik, eğitimin engellenmesi ve ssrarlı takip çerçevesinde ilk kez veri toplanmıştır. $\mathrm{Bu}$ verilere göre, Türkiye genelinde kadınların \%26's1 18 yaşından önce evlenmiş, \%9'u çocukluk döneminde (15 yaşından önce) cinsel istismara maruz kalmış, \%32'sinin okula devam etmesi engellenmiş, her 10 kadından yaklaşık 3'ü en az bir kez ısrarlı takibe maruz kalmıştır. Bu veriler, Türkiye'de kadınlara yönelik şiddetin bütün boyutlarıyla yaygın bir biçimde yaşandığını göstermektedir. Köşgeroğlu, Çulha ve Öz (2015) yapmış oldukları çalışmada, katılımcıların \%61'inin fiziksel, \%76'sının psikolojik, \%23'ünün ekonomik ve \%9'unun cinsel şiddete maruz kaldıklarını belirtmişlerdir. Kadına yönelik şiddetin en yüksek oranda göründüğü durumlar genellikle aile içi ilişkilerde yaşanmaktadır. Ancak çoğu aile içi şiddet olaylarının genellikle ilgili kurumlara iletilmeden kapatıldığı da bilinen bir gerçekliktir. Aile kurumunun mahremiyeti gibi kültürel normlar, özellikle aile içi şiddet vakalarının çoğunun kayıt altına alınmasına ve resmi verilere yansitılmasına engel olmaktadır. Örneğin; Yanık, Hanbaba, Soygör, Ayaltı ve Doğan (2014) Kırklareli'nde ikamet eden 900 katılımcıdan toplamış oldukları veriler çerçevesinde; kadınların \%43,4'ünün psikolojik, ekonomik, cinsel ya da fiziksel şiddete maruz kaldıkları halde yalnızca \%2'sinin karakola gidip şikâyetçi olduğunu aktarmaktadır. Benzer olarak Karal ve Aydemir (2012) şiddet mağdurlarının \%92'sinin herhangi bir kuruma başvurmadığını ifade etmişlerdir. Bireylerin şiddeti algılama biçimleri de yaşadıkları toplumun kültürüne, eğitim düzeyine, yasalarına ve sosyo-ekonomik durumuna göre değişmektedir (Güler, Tel ve Özkan-Tuncay, 2005). Türkiye'de aile içi şiddet bir "terbiye etme" biçimi olarak algılanmakta ve bu alg1 şiddetin sürekli olarak kendini yeniden üretmesine yol açabilmektedir (Page ve İnce, 2008, s.83). Çalışkan ve Çevik (2018) Türkiye'de kadına yönelik şiddetin belirleyicileri olarak; şiddeti algılama biçimini ve kadının sosyo-ekonomik ve psikolojik durumunu göstermişlerdir.

Kadına yönelik şiddetle mücadele bağlamında dünya genelinde uluslararası kuruluşlar tarafından birçok proje yürütülmekte ve devletlerin bu konuda aldıkları önlemlerin takip edilmesi için kurulan çeşitli mekanizmalar aracılığıyla izleme çalışmaları yapılmaktadır. 
Türkiye'de kadın-erkek eşitliğinin devletin sorumluluğu olarak kabul edilmesi bağlamında ele alındığında, devlet mekanizması içerisinde bu eşitliği hayata geçirmek için gereken kurumsal örgütlenme, 1980'lerin sonlarından itibaren mümkün olmuştur. Türkiye'nin taraf olduğu sözleşmeler ve uluslararası taahhütleri çerçevesinde atılan bu adımların en önemlilerinden biri, 2004 yılında Türkiye Cumhuriyeti Anayasası'nın 10. Maddesine eklenen "Kadınlar ve erkekler eşit haklara sahiptir. Devlet, bu eşitliğin yaşama geçmesini sağlamakla yükümlüdür" ifadesidir. Böylece Anayasa ve yasalarda kadın-erkek eşitliği ilkesi güçlendirilmiş (KSGM, 2012), kadına yönelik şiddetle mücadelenin de devletin kurumsal çatısı altında yürütülmesini sağlayacak mekanizmaların etkinleştirilmesi sağlanmıştır. Bu çerçevede, 11 Ekim 2005 tarihinde "Töre ve Namus Cinayetleri ile Kadınlara ve Çocuklara Yönelik Şiddetin Sebeplerinin Araştırılarak Alınması Gereken Önlemlerin Belirlenmesi” amaciyla Türkiye Büyük Millet Meclisi'nde (TBMM) meclis araştırma komisyonu kurulmuş ve 2006/17 sayılı Başbakanlık Genelgesi yayınlanmıştır. Bu genelge kapsamında ilgili kurum ve kuruluşlar ile üniversiteler, sivil toplum kuruluşları ve medyaya yönelik somut görevler tanımlanmıştır (KSGM, 2006, s.6). Kadına yönelik şiddeti engellemeye yönelik adımlar belirli bir kurum ile sınırlı tutulmamış; Kadın ve Aileden Sorumlu Bakanlık başta İçişleri Bakanlığı olmak üzere Sağlık, Adalet ve Diyanet İşlerinden Sorumlu Devlet Bakanlıkları ile çeşitli protokoller imzalamıştır.

KSGM 2007 yılından itibaren orta vadeli eylem planları hazırlamaktadır. Bu eylem planlarından birisi olan 2007-2010 Ulusal Eylem Planı'nın altı temel hedefinden ikincisi: "Aile içi şiddeti doğuran ve pekişstiren olumsuz tutum ve davranışların ortadan kaldırlması amaciyla, toplumsal cinsiyet eşitliği ve kadına yönelik aile içi şiddet konularında toplumsal farkındalık yaratmak ve zihinsel dönüşüm sağlamak" olarak ifade edilmiştir (KSGM, 2006). $\mathrm{Bu}$ hedefin ikinci, üçüncü, dördüncü ve yedinci maddeleri doğrudan öğretmenlerle ve öğretmen yetiştirme süreçleri ile ilişkilendirilebilir. Eylem Planı'nın ikinci hedefinin alt başlıklarında toplumsal cinsiyet eşitliği ve aile içi şiddetle mücadele amacıyla görsel ve basılı materyallerin hazırlanması ve bilgilendirme etkinliklerinin düzenlenmesi; erkeklere yönelik farkındalık yaratma ve zihinsel dönüşüm sağlama amacıyla materyaller hazırlanması ve eğitim programlarının düzenlenmesi, olumsuz rol modellerinin eğitim materyallerinden çıkartılması ve olumlu rol modellerine yer verilmesi; örgün ve yaygın eğitim programlarında toplumsal cinsiyet eşitliği ve kadına yönelik aile içi şiddetin önlenmesi ile ilgili konuların eklenmesi ve son olarak eğitim, hukuk, tıp, iletişim ve diğer ilgili fakültelerin lisans programlarında bu konulara yer verilmesi beklenmektedir.

$\mathrm{Bu}$ hedef çerçevesinde Millî Eğitim Bakanlı̆̆ tarafından "Anne-Baba-Çocuk Eğitimi Projesi" kapsamında üreme sağlığı, ergen ilişkileri, aile içi ilişkiler, kadının toplumdaki yeri ve önemi vb. başlıklarda konferanslar, paneller, ev ziyaretleri gibi etkinlikler gerçekleştirilmiştir (KSGM, 2012). 2013 yllında Eğitimde Cinsiyet Eşitliğinin Desteklenmesi Projesi yaşama geçirilmiştir. KSGM tarafindan hazırlanan 2012-2015 yılları arasını kapsayan stratejik plan kapsamında farkındalık yaratma ve zihinsel dönüşümün sağlanması amacıyla bir önceki eylem planındaki hedefin aynen tekrar edildiği görülmektedir.

Genel olarak 2007-2010 ve 2012-2015 eylem planları arasında bazı benzerlikler dikkat çekmektedir. 2012-2015 Eylem Planı'nda etkinliklerin kapsamının biraz genişletildiği görülmektedir. Örneğin; 2012-2015 Eylem Planı madde 2.7.'de "fakültelerin lisans programlarında yer verilmesi" yönergesi varken, 2012-2015 Eylem Planı'nda "mezuniyet öncesi ve sonrasında" ifadesi getirilerek uygulanma süresi genişletilmiştir. Ayrıca 20072010 Eylem Planı'nda "aile içi şiddet” kavramının 2012-2015 Eylem Planı içinde "ev içi şiddet" ifadesine çevrildiği dikkat çekmektedir. Bu durum yasal olarak evli olmayan ancak aynı evi paylaşan bireyler arasındaki şiddet eylemlerini de kapsaması açısından önemlidir. 2016 yılında yayımlanan 2016-2020 Ulusal Eylem Planı'nda yapısal değiş̧ikliklere gidildiği görülmektedir. 
Kadına yönelik şiddet sorununun çözümüne yönelik yasal alanda atılmış adımların yanı sıra, diğer kurum ve kuruluşları da sorunun çözümünde birer paydaş olarak tanımlaması açısından, eylem planları büyük önem arz etmektedir. Türkiye'de KSGM tarafından hazırlanmış 2007-2010, 2012-2015 ve 2016-2020 Eylem Planlarında kadına yönelik şiddetin önlenmesine yönelik hedeflerde eğitim önemli bir boyutu oluşturmaktadır. Çocukların, aile içinde ya da dışında toplumsal yaşamın her alanında mağduru, faili ya da tanığ1 olabilecekleri şiddet olaylarının engellenmesinde önemli görevlerden birisi de okullara düşmektedir. Her ne kadar öğretim programlarında, ders kitaplarında, medyada bilinçlendirmeye ve farkındalık yaratmaya yönelik uyaranlar yer alsa da ilk ve ortaokul düzeyinde öğrencilerin yaşantılarında kalıcı farkındalık sağlanmasında öğretmenler rol model olabilmektedir. Bir birey olarak öğretmenin sahip olduğu tutum ve davranışlarını sınıf içerisine taşımamasını beklemek gerçekçi değildir. Öğretmenler bilinçli ya da bilinçsiz olarak söyledikleri sözler ve yaptıkları davranışlarla öğrencilerin şiddeti anlamlandırmalarında olumlu ya da olumsuz örnek olabilmektedir. Öğretmenlerin bu çerçevede hizmet öncesi dönemde toplumsal cinsiyet eşitliğine yönelik duyarlılık ve farkındalık eğitimleri almaları gerekmektedir. Öğretmenlerin ve öğretmen adaylarının alacakları eğitimlerin etkisinin değerlendirilebilmesi ve tutumlarını etkileyen faktörlerin belirlenmesi, alacakları eğitimin planlanmasında yardımcı bir veri sağlayacaktır. Öğretmenlerin hizmet öncesi dönemde kadına yönelik şiddet tutumlarının belirlenmesi ve bu belirlemeye dayalı olarak gerekli eğitimlerle farkındalık kazanmaları önemlidir. $\mathrm{Bu}$ araştırmanın, öğretmen adaylarının kadına yönelik şiddet tutumlarını etkileyen değişkenlerin belirlenerek hizmet öncesinde aldıkları eğitimin daha etkili gerçekleşmesine katkı sağlayacağı düşünülmektedir. Özellikle yurttaşlık eğitimi sorumluluğunu üstlenen sosyal bilgiler öğretmenleri bu açıdan diğer branşlardan ayrılmaktadır. Şiddeti etkileyen birçok farklı değişken bulunmaktadır. Bu değişkenlerin başında kültürel aktarım, ekonomik sorunlar, alınan eğitim ve aile içi sosyalleşme pratikleri gelmektedir. Bu değişkenlerin hangilerinin sosyal bilgiler öğretmen adaylarının kadına yönelik şiddet tutumlarına etki ettiğinin belirlenmesi önem arz etmektedir.

Ulusal ve uluslararası alan yazında son yıllarda toplumsal cinsiyet eşitliği konusunda farkındalık geliştirilmeye yönelik çabalar olsa da kadına yönelik şiddet konusunda yapılmış çalışma sayısı yeterli değildir. Yapılan araştırmaların çoğu kadınların şiddet görme durumlarını belirlemeye yöneliktir. Bu araştırmanın, yapılacak sonraki çalışmalar için veri sağlaması açısından da önemli olabileceği düşünülmektedir.

\section{Amaç}

$\mathrm{Bu}$ çalışmanın amacı; sosyal bilgiler öğretmenliği programında öğrenim gören öğretmen adaylarının kadına yönelik şiddet tutumlarının çeşitli değişkenlere göre farklılaşıp farklılaşmadığını belirlemektir. $\mathrm{Bu}$ amaç çerçevesinde aşağıda belirtilen sorulara yanıt aranmıştır:

Sosyal bilgiler öğretmen adaylarının kadına yönelik şiddet tutum puanları:

1. Cinsiyete göre farklılaşmakta mıdır?

2. Öğrenim gördükleri üniversiteye göre farklılaşmakta mıdır?

3. Öğrenim gördükleri sınıf düzeyine göre farklılaşmakta mıdır?

4. Kız kardeş sayısına göre farklılaşmakta mıdır?

5. Erkek kardeş sayısına göre farklılaşmakta mıdır?

6. Anne eğitim durumuna göre farklılaşmakta mıdır?

7. Baba eğitim durumuna göre farklılaşmakta mıdır?

8. Bir öğrenci topluluğuna üye olma durumuna göre farklılaşmakta mıdır?

9. Romantik bir ilişki yaşamış olma durumuna göre farklılaşmakta mıdır?

10. Romantik bir ilişkiyi sürdürüyor olma durumuna göre farklılaşmakta mıdır?

11. Aile içi şiddete tanık olma durumuna göre farklılaşmakta mıdır? 


\section{Yöntem}

\section{Araștırmanın modeli}

$\mathrm{Bu}$ araştırma, sosyal bilgiler branşı öğretmen adaylarının kadına yönelik şiddet tutumlarının belirlenmesi amaciyla betimsel bir araştırma olarak modellenmiştir. Bu modelde var olan bir durum, olduğu gibi betimlenmeye çalışılmaktadır (Karasar, 2004, s.77).

\section{Çalıșma Grubu}

Araştırmaya katk1 sağlayan katılımcılar altı farklı devlet üniversitesinde öğrenim gören sosyal bilgiler öğretmen adaylarıdır. Çalışma grubunun yalnızca sosyal bilgiler branşından seçilmesinin nedeni, sosyal bilgiler disiplininin yurttaşlık eğitimi kapsamında haklar ve hakların öğretiminden doğrudan sorumlu ders olmasıdır. Kadına yönelik şiddet gibi hassas bir konu çalışıldığ için evrene ve evreni temsil edebilecek örnekleme ulaşmada çeşitli zorluklar yaşanmıştır. Bu nedenle bir çalışma grubu oluşturulmuştur. Ölçme araçlarının uygulandığı çalışma grubu katılımcıları, "sosyal bilgiler branşından öğretmen adayı olma" durumu dikkate alınarak uygun durum örneklemesi tekniğiyle seçilmiştir. Bu örnekleme türünde araştırma yapılacak grupların araştırmaya dahil edilmesinde kolay ulaşılabilir olmaları ön plana çıkmaktadır (Ekiz, 2009, s.106). Veri toplama arac1 950 sosyal bilgiler öğretmen adayına uygulanmıştır. Veri analizleri öncesi katılımcı yanıtları incelenmiş, ölçek maddelerinin önemli bir bölümünü doldurmayan (en az \%5'ini) ya da merkeze kayma hataları gözlenen toplam sekiz kişiye ait veriler çıkarılmıştır. Yapılan aykırı değer analizleri sonucunda da dört gözlem analiz dışı bırakılmıştır ve sonuçta analizler toplam 938 katılımcıdan elde edilen verilerle gerçekleştirilmiştir. Araştırmaya katılan bireylerin çeşitli değişkenlere göre dağılımı Tablo 1'de sunulmuştur.

Tablo 1. Öğrencilerin bölüm, sınıf düzeyi ve cinsiyete göre dağılımı

\begin{tabular}{|c|c|c|c|}
\hline \multicolumn{2}{|c|}{ Değişken } & $\mathbf{n}$ & $\%$ \\
\hline \multirow{2}{*}{ Cinsiyet } & Kadın & 541 & 57,7 \\
\hline & Erkek & 397 & 42,3 \\
\hline \multirow{6}{*}{ Üniversite } & 1 & 157 & 16,7 \\
\hline & 2 & 178 & 19,0 \\
\hline & 3 & 173 & 18,4 \\
\hline & 4 & 121 & 12,9 \\
\hline & 5 & 177 & 18,9 \\
\hline & 6 & 132 & 14,1 \\
\hline \multirow{4}{*}{ Sınıf } & 1 & 276 & 29,4 \\
\hline & 2 & 276 & 29,4 \\
\hline & 3 & 221 & 23,6 \\
\hline & 4 & 165 & 17,6 \\
\hline \multirow{5}{*}{ Kız kardeş Sayısı } & 0 & 244 & 26,0 \\
\hline & 1 & 287 & 30,6 \\
\hline & 2 & 176 & 18,8 \\
\hline & 3 & 105 & 11,2 \\
\hline & 4 & 91 & 9,7 \\
\hline \multirow{3}{*}{ Erkek Kardeş Sayısı } & 0 & 263 & 28,0 \\
\hline & 1 & 375 & 40,0 \\
\hline & 2 & 157 & 16,7 \\
\hline
\end{tabular}




\begin{tabular}{|c|c|c|c|}
\hline & 3 & 91 & 9,7 \\
\hline & 4 & 28 & 3,0 \\
\hline \multirow{6}{*}{ Anne Eğitim Durumu } & İlkokul & 163 & 17,4 \\
\hline & Ortaokul & 496 & 52,9 \\
\hline & Lise & 147 & 15,7 \\
\hline & Yüksekokul & 96 & 10,2 \\
\hline & Lisans & 15 & 1,6 \\
\hline & Lisansüstü & 21 & 2,2 \\
\hline \multirow{6}{*}{ Baba Eğitim durumu } & İlkokul & 38 & 4,1 \\
\hline & Ortaokul & 366 & 39,0 \\
\hline & Lise & 216 & 23,0 \\
\hline & Yüksekokul & 214 & 22,8 \\
\hline & Lisans & 50 & 5,3 \\
\hline & Lisansüstü & 54 & 5,8 \\
\hline \multirow{4}{*}{ Aylık Ortalama Gelir } & $0-400 \mathrm{TL}$ & 705 & 75,2 \\
\hline & $401-700 \mathrm{TL}$ & 156 & 16,6 \\
\hline & $700-1000 \mathrm{TL}$ & 46 & 4,9 \\
\hline & $+1000 \mathrm{TL}$ & 31 & 3,3 \\
\hline \multirow{2}{*}{ Topluluk Üyeliği } & Evet & 156 & 16,6 \\
\hline & Hayır & 782 & 83,4 \\
\hline \multirow{2}{*}{$\begin{array}{l}\text { Romantik İlişki } \\
\text { Yürütme Durumu }\end{array}$} & Evet & 533 & 56,8 \\
\hline & Hayır & 405 & 43,2 \\
\hline \multirow{2}{*}{$\begin{array}{c}\text { İlişkinin Devam Etme } \\
\text { Durumu }\end{array}$} & Evet & 271 & 28,9 \\
\hline & Hayır & 667 & 71,1 \\
\hline \multirow{2}{*}{$\begin{array}{c}\text { Aile İçi Şiddete Tanık } \\
\text { Olma Durumu }\end{array}$} & Evet & 386 & 41,2 \\
\hline & Hayır & 552 & 58,8 \\
\hline \multicolumn{2}{|c|}{ Toplam } & 938 & 100,0 \\
\hline
\end{tabular}

\section{Veri Toplama Araci}

Araştırmada veriler, Usta, Keleşoğlu ve Esen (2017) tarafından geliştirilen "Kadına Yönelik Şiddet Tutum Ölçeğì" (KYŞTÖ) kullanılarak toplanmıştır. Tutum ölçeğinde öncelikle katılımcılardan cinsiyet, öğrenim görülen üniversite, kardeș sayısı, anne-baba eğitim durumu gibi demografik özellikleri belirtmeleri istenmektedir. KYŞTÖ, bir bireyin, kadına yönelik şiddete ilişkin tutumunu ölçmektedir. Ölçek 22 maddeden ve "bireysel alg1", "bireysel sorumluluk" ve "sosyo-kültürel ve ekonomik düzey" olmak üzere üç alt faktörden oluşmaktadır. Bu 22 madde toplam varyansın \% 44,53'ünü açıklamaktadır. Ölçekten maksimum alınabilecek puan 110 iken minumum değer ise 22'dir. Ölçek geliştirme çalışmasında, Doğrulayıcı Faktör Analizi (DFA) yapılarak, ölçeğin üç faktörlü yapısı olduğu doğrulanmıştır. Güvenirlik amaciyla hesaplanan iç tutarlılık değeri ise (.87) ölçeğin güvenilir olduğunu göstermektedir. Bu araştırma kapsamında da ölçeğin geçerliği ve güvenirliği test edilmiştir. KMO ve Barlett testi sonuçlarına göre $(\mathrm{KMO}=0.90 ; \mathrm{X} 2=5446.06 ; \mathrm{p}=0.00)$ veri grubunun faktör analizine uygun olduğu belirlenmiştir. Veriler üzerinde Temel Bileşenler Analizi yapılarak ölçeğin 3 faktörlü bir yapıda olduğu ve açıkladığı toplam varyansın 43.72 olduğu görülmüştür. Analiz sonucunda elde edilen 3 faktörlü yapıya ilişkin sonuçlar Tablo 2'de sunulmuştur. 
Tablo 2. Faktör Analizi Sonuçları

\begin{tabular}{|c|c|c|c|}
\hline & & Faktörle & \\
\hline $\begin{array}{l}\text { Madde } \\
\text { No }\end{array}$ & $\begin{array}{c}\text { Bireysel } \\
\text { Algı }\end{array}$ & Bireysel Sorumluluk & $\begin{array}{l}\text { Sosyo-Kültürel ve } \\
\text { Ekonomik Düzey }\end{array}$ \\
\hline 1 & ,756 & & \\
\hline 2 & ,730 & & \\
\hline 3 & ,693 & & \\
\hline 4 & ,693 & & \\
\hline 5 & 671 & & \\
\hline 6 & ,628 & & \\
\hline 7 & ,603 & & \\
\hline 8 & ,578 & & \\
\hline 9 &, 545 & & \\
\hline 10 & ,497 & & \\
\hline 11 & & 670 & \\
\hline 12 & & ,646 & \\
\hline 13 & & ,639 & \\
\hline 14 & & 609 & \\
\hline 15 & &, 507 & \\
\hline 16 & & ,484 & \\
\hline 17 & & ,466 & \\
\hline 18 & & ,392 & \\
\hline 19 & & & ,708 \\
\hline 20 & & & ,679 \\
\hline 21 & & & ,672 \\
\hline 22 & & & ,546 \\
\hline
\end{tabular}

KYŞÖ’nün madde yük değerleri ise .39 ile .76 arasında değişmektedir. 350 ve üzerindeki gözlem sayıları için ,30 ve üzeri kabul edilebilir (Hair vd, 1998'den aktaran: Kalaycı, 2006, s.330). Ölçeğin yapı geçerliliğinin incelenmesi için Açımlayıcı Faktör Analizine (AÇA) ek olarak, LISREL programı kullanılarak Doğrulayıcı (confirmatory) Faktör Analizi (DFA) yapılmıştır. $\mathrm{Bu}$ sayede gözlenen verinin 3 boyutlu modele ne oranda uyum sağladığını belirlemek amaçlanmıştır. DFA, gözlenebilir faktörlerden oluşan faktöriyel bir modelin gerçek verilerle ne derece uyum gösterdiğini değerlendirmeyi amaçlamaktadır (Şimşek, 2007). Yapısal Eşitlik Modelleri (YEM) arasında birçok farklı uyum indeksi bulunmaktadır. Bunlardan en yaygin olarak kullanılanı Ki Kare $\left(\mathrm{x}^{2}\right)$ testidir. Modelin veriye uyumunu tanımlamada kullanılan diğer bir yol da Ki Kare'nin serbestlik derecesine oranının hesaplanmasıdır. $\mathrm{Bu}$ oranın 5 ve altında olması kabul edilebilir bir değer olarak belirtilmektedir (Klein, 2005). En çok kullanılan uyum indeksleri "İyilik Uyum İndeksi (Goodness of Fit Index, GFI"), "Düzeltilmiş İyilik Uyum İndeksi (Adjusted Goodness of Fit Index, AGFI)", "Ortalama Hataların Karekökü (Root Mean Square Residual, RMR)", "Yaklaşık Hataların Ortalama Karekökü (Root Mean Square Error of Approximation (RMSEA)" ve "Karşılaştırmalı Uyum İndeksi (Comparative Fit Index, CFI)" dir. Bu araştırmada ölçüt olarak sayılan uyum indeksleri kullanılmışıı. GFI, AGFI, NFI, NNFI ve 
CFI'nın değerinin .90 ve üzerinde olması iyi uyum olarak; RMR ya da RMSEA değerinin ise .05 ve altında olması mükemmel uyumu, .08 ve altında olması ise kabul edilebilir uyum olarak kabul edilmektedir (Şimşek, 2007). KYŞÖ'nin AFA ile ortaya konan 3 faktörlü yapısını sınamak için yapılan DFA sonuçları Tablo 3'te sunulmuştur.

Tablo 3. KYŞÖ'nün Faktör Yapısı İçin İyilik Uyum İndeksleri

\begin{tabular}{cc}
\hline İyilik Uyum İndeksi & Değer \\
\hline $\mathbf{X}^{2} / \mathbf{s d}$ & 3,02 \\
\hline GFI &, 94 \\
\hline AGFI &, 92 \\
\hline CFI &, 93 \\
NFI &, 91 \\
\hline NNFI &, 92 \\
\hline RMR &, 060 \\
\hline RMSEA &, 052 \\
\hline
\end{tabular}

DFA ile hesaplanan $\left(\mathrm{X}^{2} / \mathrm{sd}\right)$ oran1 3,02 oranı önerilen faktör modelinin verilerle uyumlu olduğunu göstermektedir (Sümer, 2000; Şimşek, 2007). GFI değerinin .94, AGFI değerinin .92 ve CFI değerinin .93, NFI değerinin .91, NNFI değerinin .92; RMR değerinin .06 ve RMSEA değerinin de .05 bulunmuş olması, DFA sonucunda ölçeğin 3 faktörlü yapısının kabul edilebilir ve geçerli sonuçlar verdiğini göstermektedir. Ölçeğin güvenirliğini belirlemek amacıyla in Cronbach Alfa ile değerlendirilen iç tutarlılık katsayısı hesaplanmıştır. Ölçeğin Cronbach Alfa güvenirlik katsayısı bireysel algı faktörü için .72, bireysel sorumluluk faktörü için .82, sosyo-külttürel ve ekonomik faktör için .74 ve ölçeğin tamamı için .78 olarak bulunmuştur. Bu puanlara göre ölçeğin iç tutarlılığının sağlandığ ifade edilebilir. Tüm bu bulgular ışığında KYŞÖ geçerli ve güvenir bir ölçektir denilebilir.

\section{Verilerin Analizi}

Araştırmadan verilerin analizi için SPSS 16.00 (Sosyal Bilimler İçin İstatistik Programı) ve LISREL paket programları kullanılmıştır. Katılımcıların demografik özelliklerinin analizinde frekans ve yüzde dağılımı; kadına yönelik şiddetin demografik değişkenlere göre farklılaşıp farklılaşmadığını belirlemek amacıyla, tutum ölçeğinden alınan toplam puanlar üzerinden ilişkisiz örneklemler için t-testi ve ilişkisiz örneklemler için tek-yönlü varyans analizi (ANOVA) uygulanmıştır. Varyans analizinde gruplar arası farkları belirlemek için, çoklu-karşılaştırma testlerinden geçirgenliği düşük olduğu için Scheffe testi tercih edilmiştir. Verilerin analizinde güven aralığı .05 olarak alınmıştır.

\section{Verilerin Toplanması}

Araştırmada veriler ders saatleri içerisinde dersin yürütücünden izin alınarak sınıflar halinde toplanmıştır. Veriler toplanırken gönüllülük ilkesine uygun hareket edilmiş, katılımcılara araştırmanın amacı açıklanmış ve istedikleri takdirde çalışmaya katılabilecekleri belirtilmiştir. Katılımcılardan ölçeğin birinci bölümündeki demografik bilgileri dışında herhangi bir ek bilgi talebinde bulunulmamıştır. Ölçeğin uygulanması ortalama 15 dakika sürmüştür. Araştırma verileri Şubat 2017- Mayıs 2017 tarihleri arasında toplanmıştır. 


\section{Bulgular}

\section{Cinsiyet Değișkeni Açısından KYȘTÖ Ortalama Puanlarına İlișkin Bulgular}

Kadına yönelik şiddetin en önemli belirleyicisi cinsiyettir. Doğrudan kadın cinsiyetini hedef alan bu şiddet türünde hem kadınların hem de erkeklerin tutumlarının belirlenmesi önemlidir. Çünkü toplumsal ve kültürel normlar açısından şiddetin mağduru olan kadınlar da kadına yönelik şiddeti normal bir durum gibi algılayabilmektedir. Katılımcıların cinsiyet değişkeni açısından puanlarının dağılımı Tablo 4'te sunulmuştur.

\begin{tabular}{|c|c|c|c|c|c|c|}
\hline Cinsiyet & $\mathbf{N}$ & $\overline{\mathbf{X}}$ & $\mathbf{S}$ & $\mathbf{t}$ & Sd & $\mathbf{p}$ \\
\hline Kadın & 540 & 82,5167 & 8,57325 & 12,68 & 935 & ,000 \\
\hline Erkek & 397 & 74,6171 & 10,46058 & & & \\
\hline
\end{tabular}

4.

Katılımcıların KYŞÖ Puanlarının Cinsiyete Göre t-Testi Sonuçları

Analiz sonuçlarına göre, katılımcıların ölçekten aldıkları ortalama puanlar cinsiyete göre anlamlı bir farklılık göstermektedir [t(935) $=10,82, \mathrm{p}<.001]$. Kadın katılımcıların ölçekten aldıkları ortalama puan ( $\overline{\mathbf{X}}=82,51)$, erkek katılımcıların ölçekten aldıkları ortalama puandan $(\overline{\mathbf{X}}=74,61)$ daha yüksektir. Bu bulgu, kadın katılımcıların kadına yönelik şiddete dönük tutumlarının erkeklere göre anlamlı biçimde daha olumlu olduğuna işaret etmektedir. Kadına yönelik şiddetin doğrudan ya da dolaylı olarak tarafı olan kadınların bu konuda daha olumlu bir tutuma sahip oldukları görülmektedir. Toplum genelinde bazı durumlarda kadınlar da erkeklerin kadına yönelik şiddet uygulamalarını onaylamakta ve erkekleri haklı bulmaktadır. Bu bulgu ve yorum Şenol ve Yıldız'ın (2013) araştırma sonucu ile benzerlik göstermektedir. 3500 kadının katılımı ile yapılan araştırma sonucunda katılımcıların \%14,9’u şiddetin "bazen gerekli” olduğunu ifade etmişlerdir.

\section{Üniversite Değişkeni Açısından KYŞTÖ Ortalama Puanlarına Illişkin Bulgular}

Bireylerin kadına yönelik şiddet tutumlarını etkileyecek önemli bir diğer değişken eğitim aldıkları ve içinde yaşadıkları üniversite kültürüdür. Eğitimin ve özellikle de üniversite kültürünün demokratik değerleri geliştirmesi ve buna bağlı olarak da şiddete ilişkin bakış açısını olumlu yönde değiştirmesi beklenir. Katılımcıların eğitim aldıkları üniversite ile ölçekten aldıkları puan arasında anlamlı ilişki olup olmadığına ilişkin ANOVA sonuçları Tablo 5'te sunulmuştur.

Tablo 5. Katıımcıların KYŞÖ Puanlarının Eğitim Aldıkları Üniversiteye Göre ANOVA Sonuçları

\begin{tabular}{|c|c|c|c|c|c|c|}
\hline $\begin{array}{l}\text { Varyansın } \\
\text { Kaynağı }\end{array}$ & $\begin{array}{l}\text { Kareler } \\
\text { Toplamı }\end{array}$ & sd & $\begin{array}{c}\text { Kareler } \\
\text { Ortalaması }\end{array}$ & $\mathbf{F}$ & $\mathbf{p}$ & Anlamlı Fark \\
\hline Gruplararası & 6866,113 & 5 & 1373,223 & 14,149 & ,000 & $1-2,1-3,1-4,1-5,1-6$ \\
\hline Gruplariçi & 90359,906 & 931 & 97,057 & & & \\
\hline Toplam & 97226,019 & 936 & & & & \\
\hline
\end{tabular}

Analiz sonuçları, katılımcıların eğitim aldıkları üniversite açısından ölçekten aldıkları puanda anlamlı bir fark olduğunu göstermektedir $[\mathrm{F}(5-936)=14,149, \mathrm{p}<.001]$. Başka bir ifade ile katılımcıların eğitim aldıkları üniversiteye göre kadına yönelik tutumları farklılaşmaktadır. Ortalama puan farklarının hangi üniversite gruplarından kaynaklandığını belirlemek amacıyla yapılan Scheffe testinin sonuçlarına göre, 1 numaralı üniversitedeki 
( $\overline{\mathbf{X}}=84,77)$ katılımcıların ölçekten aldıkları puanlar diğer üniversitelerde eğitim alan katılımcılara göre anlamlı düzeyde daha yüksektir. Üniversiteye göre ölçekten alınan ortalama puanlar ve standart sapmalar Tablo 6'da sunulmaktadır.

Tablo 6. Katıımcıların KYŞÖ Puanlarının Eğitim Aldıkları Üniversiteye Göre Ortalama Puanları ve Standart Sapmaları

\begin{tabular}{cccccc}
\hline & $\mathbf{N}$ & $\overline{\mathbf{X}}$ & Ss & Minimum & Maksimum \\
\hline $\mathbf{1}$ & 157 & 84,7707 & 8,09627 & 56,00 & 98,00 \\
\hline $\mathbf{2}$ & 178 & 78,9831 & 11,89002 & 43,00 & 100,00 \\
\hline $\mathbf{3}$ & 172 & 79,2616 & 9,01760 & 53,00 & 97,00 \\
\hline $\mathbf{4}$ & 121 & 77,0661 & 8,73950 & 54,00 & 94,00 \\
\hline $\mathbf{5}$ & 177 & 76,5028 & 10,46755 & 34,00 & 100,00 \\
\hline $\mathbf{6}$ & 132 & 78,1439 & 9,86793 & 40,00 & 95,00 \\
\hline Toplam & 937 & 79,1697 & 10,19186 & 34,00 & 100,00 \\
\hline
\end{tabular}

1 numaralı üniversitede öğrenim gören öğretmen adaylarının tutum puanlarının diğer üniversitelere göre yüksek olduğu görülmektedir. İlgili üniversitede öğretmen adaylarına yönelik "Toplumsal Cinsiyet ve Eğitim" adlı seçmeli bir ders yürütülmektedir. Katılımcılar arasındaki bu farkın söz konusu derse devam etmiş olan öğretmen adaylarının puanlarından etkilendiği düşünülmektedir. UNICEF'in 2003 yılı Türkiye Raporu'na göre öğretmenlerin içinde yaşamış oldukları toplumsal ortam, toplumsallaşma biçimleri ve eğitimleri genellikle toplumsal cinsiyet eşitsizliğini sorgulamalarını engellemektedir (UNICEF, 2003). Öğretmen adaylarının bu konuya ilişkin sorgulamalarının sağlanabilmesi için "toplumsal cinsiyet", "kadına yönelik şiddet", "kadın hakları" vb. bilgilerin sunulduğu, adalet, eşitlik, saygı vb. değerlerin kazandırıldığı derslerin öğretmen yetiştirme programlarında yer almasının kadına yönelik şiddet tutumu üzerinde anlamlı derecede fark yaratacağ düşüncesini destekleyen bir bulguya ulaşılmıştır.

\section{Sınıf Düzeyi Değișkeni Açısından KYȘTÖ Ortalama Puanlarına Ilișkin Bulgular}

Katılımcıların sınıf düzeyleri ile ölçekten aldıkları puan arasında anlamlı ilişki olup olmadığına ilişkin ANOVA sonuçları Tablo 7'de sunulmuştur.

Tablo 7. Katıımcıların KYŞÖ Puanlarının Sınıf Düzeylerine Göre ANOVA Sonuçları

\begin{tabular}{ccccccc}
\hline $\begin{array}{c}\text { Varyansın } \\
\text { Kaynağı }\end{array}$ & $\begin{array}{c}\text { Kareler } \\
\text { Toplamı }\end{array}$ & sd & $\begin{array}{c}\text { Kareler } \\
\text { Ortalaması }\end{array}$ & F & p & Anlamlı Fark \\
\hline Gruplararası & 481,764 & 3 & 160,588 & 1,549 &, 200 & \\
\hline Gruplariçi & 96744,255 & 933 & 103,692 & & & \\
\hline Toplam & 97226,019 & 936 & & & \\
\hline
\end{tabular}

Analiz sonuçları, katılımcıların sınıf düzeyleri açısından ölçekten aldıkları puanda anlamlı bir fark olmadığını göstermektedir [F(3-936) $=1,54, \mathrm{p}>.05]$.

\section{Kız Kardeș Sayısı Deģișkeni Açısından KYȘTÖ Ortalama Puanlarına İlişkin Bulgular}

Katılımcıların KYŞTÖ ortalama puanlarının kız kardeş sayısı değişkenine göre değişip değişmediğine iliş̧in ANOVA sonuçları Tablo 8'de sunulmuştur. 
Tablo 8. Katılımcıların KYŞÖ Puanlarının Kız Kardeş Sayılarına Göre ANOVA Sonuçları

\begin{tabular}{ccccccc}
\hline $\begin{array}{c}\text { Varyansın } \\
\text { Kaynağı }\end{array}$ & $\begin{array}{c}\text { Kareler } \\
\text { Toplamı }\end{array}$ & sd & $\begin{array}{c}\text { Kareler } \\
\text { Ortalaması }\end{array}$ & F & p & Anlamlı Fark \\
\hline Gruplararası & 656,007 & 5 & 131,201 & 1,265 &, 277 \\
\hline Gruplariçi & 96570,012 & 931 & 103,727 & & & - \\
\hline Toplam & 97226,019 & 936 & & & \\
\hline
\end{tabular}

Analiz sonuçları, katılımcıların kız kardeş sayıları açısından ölçekten aldıkları puanda anlamlı bir fark olmadığını göstermektedir $[\mathrm{F}(5-936)=1,265, \mathrm{p}>.05]$. Başka bir ifade ile katılımcıların kız kardeş sayılarına göre kadına yönelik şiddet tutum puanları farklılaşmamaktadır.

\section{Erkek Kardeș Sayısı Değișkeni Açısından KYȘTÖ Ortalama Puanlarına İlișkin Bulgular}

Katılımcıların KYŞTÖ ortalama puanlarının erkek kardeş sayısı değişkenine göre değişip değişmediğine iliş̧in ANOVA sonuçları Tablo 9'da sunulmuştur.

Tablo 9. Katılımcıların KYŞÖ Puanlarının Erkek Kardeş Sayılarına Göre ANOVA Sonuçları

\begin{tabular}{ccccccc}
\hline $\begin{array}{c}\text { Varyansın } \\
\text { Kaynağı }\end{array}$ & $\begin{array}{c}\text { Kareler } \\
\text { Toplamı }\end{array}$ & sd & $\begin{array}{c}\text { Kareler } \\
\text { Ortalaması }\end{array}$ & $\mathbf{F}$ & $\mathbf{p}$ & Anlamlı Fark \\
\hline Gruplararası & 1829,401 & 5 & 365,880 & 3,571 &, 003 & $0-3$ \\
\hline Gruplariçi & 95396,618 & 931 & 102,467 & & & \\
\hline Toplam & 97226,019 & 936 & & & & \\
\hline
\end{tabular}

Analiz sonuçları, katılımcıların erkek kardeş sayıları açısından ölçekten aldıkları puanda anlamlı bir fark olduğunu göstermektedir $[\mathrm{F}(5-936)=3,571, \mathrm{p}<.05]$. Ortalama puan farklarının hangi gruplar arasında olduğunu bulmak amaciyla yapılan Scheffe testinin sonuçlarına göre, hiç erkek kardeşi olmayan ( $\overline{\mathbf{X}}=80,98$ ) katılımcıların ölçekten aldıkları puanlar 3 erkek kardeşi olanlara göre anlamlı biçimde daha yüksektir. Erkek kardeş sayılarına göre ölçekten alınan ortalama puanlar ve standart sapmalar Tablo 10'da sunulmuştur.

Tablo 10. Katılımcıların KYŞÖ Puanlarının Erkek Kardeş Sayısına Göre Ortalama Puanları ve Standart Sapmaları

\begin{tabular}{cccccc}
\hline & $\mathbf{N}$ & $\overline{\mathbf{X}}$ & Ss & Minimum & Maksimum \\
\hline $\mathbf{0}$ & 263 & 80,9848 & 9,09449 & 56,00 & 97,00 \\
\hline $\mathbf{1}$ & 374 & 78,9866 & 11,13010 & 34,00 & 100,00 \\
\hline $\mathbf{2}$ & 157 & 78,8790 & 9,61126 & 52,00 & 98,00 \\
\hline $\mathbf{3}$ & 91 & 76,4945 & 9,56193 & 56,00 & 95,00 \\
\hline $\mathbf{4}$ & $\mathbf{2 8}$ & 76,4643 & 9,92372 & 60,00 & 96,00 \\
\hline Toplam & $\mathbf{2 4}$ & 77,3333 & 9,82750 & 64,00 & 95,00 \\
\hline
\end{tabular}

Erkek kardeş değişkeni açısından hiç erkek kardeşi olmayan katılımcıların ortalama puanlarının daha yüksek olduğu görülmektedir. Şiddet aile içinde öğrenilen ve öğretilen bir olgudur. Çocukken tanık olunan şiddetin, erkeklerin şiddet uygulama olasılığını, kadınların da şiddete maruz kalma olasılığını iki kat artırdığını belirten araştırma bulguları vardır (Altınay ve Arat, 2008). Şiddet döngüsü olarak adlandırılan bu durum, şiddetin çok küçük yaşlardan itibaren yaşanmasının ve aile içinde babanın anneye şiddet uyguladığının gözlenmesinin hem kadın hem de erkek için şiddetin normalleştirilmesine yol açabileceğini ifade etmektedir. Erkek kardeş değişkeni açısından elde edilen bulgu erkek kardeşler arasında şiddete dayalı bir ilişkinin, kimi zaman şiddetin normalleşmesine katkı 

sağlayabilen bir faktör olarak yorumlanabileceğini göstermektedir. Şiddeti normalleştirmek de kadına yönelik şiddete eğilimi arttırıyor olabilir.

\section{Anne Eğitim Düzeyi Değișkeni Açısından KYŞTÖ Ortalama Puanlarına Ilișkin Bulgular}

Eğitim düzeyi ile şiddet arasında doğrudan bir bağlantı olma olasılığı yüksektir. Eğitim bireyin haklarının farkında olması ve şiddete uğraması durumunda hangi korunma yollarına başvurabileceği bilgisini ve şiddete karşı koyma tutumunu kazandırmaktadır. Bu açıdan anne eğitim düzeyinin kadına yönelik şiddet tutumunu belirlemede bir etkisinin olup olmadığına bakılmışıı. Katılımcıların anne eğitim düzeyi ile ölçekten aldıkları puan arasında anlamlı ilişki olup olmadığına ilişkin ANOVA sonuçları Tablo 11'de sunulmuştur.

Tablo 11. Katıımcıların KYŞÖ Puanlarının Anne Eğitim Durumuna Göre ANOVA Sonuçları

\begin{tabular}{|c|c|c|c|c|c|c|}
\hline $\begin{array}{c}\text { Varyansın } \\
\text { Kaynağı }\end{array}$ & $\begin{array}{l}\text { Kareler } \\
\text { Toplamı }\end{array}$ & sd & $\begin{array}{c}\text { Kareler } \\
\text { Ortalaması }\end{array}$ & $\mathbf{F}$ & $\mathbf{p}$ & Anlamlı Fark \\
\hline Gruplararası & 3748,030 & 5 & 749,606 & 7,466 & ,000 & \multirow[t]{3}{*}{$1-2,1-3,1-4$} \\
\hline Gruplariçi & 93477,989 & 931 & 100,406 & & & \\
\hline Toplam & 97226,019 & 936 & & & & \\
\hline
\end{tabular}

Analiz sonuçları, katılımcıların anne eğitim durumu açısından ölçekten aldıkları puanda anlamlı bir fark olduğunu göstermektedir $[\mathrm{F}(5-936)=7,466, \mathrm{p}<.01]$. Ortalama puan farklarının hangi eğitim grupları arasında olduğunu bulmak amacıyla yapılan Scheffe testinin sonuçlarına göre, annesi yüksekokul mezunu olan $(X=81,70)$ katılımcıların ölçekten aldıkları puanlar, annesi ilkokul ( $\overline{\mathbf{X}}=75,05)$, ortaokul ( $\overline{\mathbf{X}}=79,96)$ ve lise mezunu ( $\overline{\mathbf{X}}=79,56$ ) olan katılımcıların puanlarından anlamlı derecede yüksektir. Anne eğitim durumuna göre ölçekten alınan ortalama puanlar ve standart sapmalar Tablo 12'de sunulmuştur.

Tablo. 12. Katııımcıların KYŞÖ Puanlarının Anne Eğitim Durumuna Göre Ortalama Puanları ve Standart Sapmaları

\begin{tabular}{cccccc}
\hline & $\mathbf{N}$ & $\overline{\mathbf{X}}$ & $\mathbf{S s}$ & Minimum & Maksimum \\
\hline Ilkokul & 163 & 75,0552 & 9,89404 & 51,00 & 98,00 \\
\hline Ortaokul & 495 & 79,9697 & 9,77816 & 34,00 & 100,00 \\
\hline Lise & 147 & 79,5646 & 10,72576 & 43,00 & 98,00 \\
\hline $\begin{array}{c}\text { Yüksekoku } \\
\mathbf{I}\end{array}$ & 96 & 81,7083 & 10,01043 & 49,00 & 100,00 \\
\hline $\begin{array}{c}\text { Lisans } \\
\text { Lisansüstü }\end{array}$ & 15 & 77,8000 & 10,42113 & 60,00 & 94,00 \\
\hline Toplam & 937 & 78,8571 & 11,29285 & 58,00 & 94,00 \\
\hline
\end{tabular}

Yanık vd. (2014) eğitim düzeyi yükseldikçe şiddete maruz kalma durumunun azaldığını belirlemişlerdir. Birçok çalışmada eğitim düzeyi ile şiddete maruz kalma arasında anlamlı farklar bulunmuştur. Köşgeroğlu vd. (2015) kadınların öğrenim düzeyleri ile şiddete maruz kalma olasılıkları arasındaki ilişkiyi inceledikleri araştırmada, ortaokul ve lise mezunu kadınların şiddete maruz kalma oranlarının üniversite mezunu kadınlara göre daha yüksek seviyede olduğu sonucuna ulaşmışlardır. Anneleri kadına yönelik şiddet konusunda bilinçli olan bireylerin tutumlarının da olumlu olabileceği düşünülmektedir. Bu bulguda dikkat 
çeken diğer bir nokta ise, anneleri lisans veya lisansüstü eğitim almış öğretmen adaylarının ortalamalarının diğer düzeylerdeki ortalama puanların altında kalmış olmasıdır.

\section{Baba Eğitim Düzeyi Değișkeni Açısından KYŞTÖ Ortalama Puanlarına Ilișkin Bulgular}

Anne eğitim düzeyi kadar babanın eğitim düzeyinin de şiddet tutumlarına etki edebileceği düşünülmektedir. Katılımcıların baba eğitim durumu ile ölçekten aldıkları puan arasında anlamlı ilişki olup olmadığına ilişskin ANOVA sonuçları Tablo 13'te sunulmuştur.

Tablo 13. Katılımcıların KYŞÖ Puanlarının Baba Eğitim Durumuna Göre ANOVA Sonuçları

\begin{tabular}{ccccccc}
\hline $\begin{array}{c}\text { Varyansın } \\
\text { Kaynağı }\end{array}$ & $\begin{array}{c}\text { Kareler } \\
\text { Toplamı }\end{array}$ & sd & $\begin{array}{c}\text { Kareler } \\
\text { Ortalaması }\end{array}$ & $\mathbf{F}$ & p & Anlamlı Fark \\
\hline Gruplararası & 1771,281 & 5 & 354,256 & 3,455 &, 004 \\
\hline Gruplariçi & 95454,738 & 931 & 102,529 & & $1-4$ \\
\hline Toplam & 97226,019 & 936 & & & \\
\hline
\end{tabular}

Analiz sonuçları, katılımcıların baba eğitim durumu açısından ölçekten aldıkları puanda anlamlı bir fark olduğunu göstermektedir $[\mathrm{F}(5-936)=3,455, \mathrm{p}<.01]$. Başka bir ifade ile katılımcıların baba eğitim durumuna göre kadına yönelik tutumları farklılaşmaktadır. Ortalama puan farklarının hangi eğitim düzeyleri arasında olduğunu bulmak amaciyla yapılan Scheffe testinin sonuçlarına göre, babası yüksekokul mezunu olan ( $\overline{\mathbf{X}}=80,83$ ) katılımcıların ölçekten aldıkları puanlar babası ilkokul mezunu ( $\overline{\mathbf{X}}=74,05)$ olanlara göre daha olumlu bir tutuma sahiptir. Baba eğitim durumuna göre ölçekten alınan ortalama puanlar ve standart sapmalar Tablo 14'te sunulmuştur.

Tablo 14. Katılımcıların KYŞÖ Puanlarının Baba Eğitim Durumuna Göre Ortalama Puanları ve Standart Sapmaları

\begin{tabular}{cccccc}
\hline & $\mathbf{N}$ & $\overline{\mathbf{X}}$ & Ss & Minimum & Maksimum \\
\hline $\mathbf{1}$ & 38 & 74,0526 & 11,18625 & 57,00 & 98,00 \\
\hline $\mathbf{2}$ & 365 & 78,7699 & 9,70395 & 40,00 & 97,00 \\
\hline $\mathbf{3}$ & 216 & 78,8472 & 10,91190 & 43,00 & 98,00 \\
\hline $\mathbf{4}$ & 214 & 80,8318 & 9,08487 & 50,00 & 100,00 \\
\hline $\mathbf{5}$ & 50 & 80,5800 & 9,66181 & 64,00 & 95,00 \\
\hline $\mathbf{6}$ & 54 & 78,8704 & 12,88124 & 34,00 & 100,00 \\
\hline Toplam & 937 & 79,1697 & 10,19186 & 34,00 & 100,00 \\
\hline
\end{tabular}

Aylık Ortalama Gider Değişkeni Açısından KYŞTÖ Ortalama Puanlarına İlişkin Bulgular

Şiddetin ortaya çıkmasını etkileyen nedenler arasında gösterilen diğer bir boyut ekonomik kaygılardır. Bireylerin ekonomik sıkıntılar yaşadıklarında şiddet davranışına başvurmayı tercih ettikleri düşünülmektedir. Katılımcıların aylık ortalama giderleri ile ölçekten aldıkları puan arasında anlamlı ilişki olup olmadığına ilişkin ANOVA sonuçları Tablo 15'te sunulmuştur.

Tablo 15. Katılımcıların KYŞÖ Puanlarının Aylık Ortalama Giderine Göre ANOVA Sonuçları

\begin{tabular}{ccccccc}
\hline $\begin{array}{c}\text { Varyansın } \\
\text { Kaynağı }\end{array}$ & $\begin{array}{c}\text { Kareler } \\
\text { Toplamı }\end{array}$ & sd & $\begin{array}{c}\text { Kareler } \\
\text { Ortalaması }\end{array}$ & F & p & Anlamlı Fark \\
\cline { 1 - 5 } Gruplararası & 294,993 & 3 & 98,331 &, 946 &, 418 & - \\
\hline Gruplariçi & 96931,026 & 933 & 103,892 & & & \\
\hline Toplam & 97226,019 & 936 & & &
\end{tabular}


Analiz sonuçları, katılımcıların aylık ortalama gider açısından ölçekten aldıkları puanda anlamlı bir fark olmadığııı göstermektedir $[\mathrm{F}(3-936)=0,946, \mathrm{p}>.05]$. Baran, Kütük ve Maybek (2012)'in araştırma sonucuna göre çalışmayan kadınlar, çalışan kadınlara göre şiddeti daha fazla meşrulaştırmaktadır. Buna karşın Thompson ve Walker (1989) ekonomik bağımsızlığını elde eden kadının erkek tarafından tehdit unsuru olarak görülüp şiddete maruz kaldığını belirtmektedir (Çakır, Harcar, Sürgevil ve Budak, 2012). Ekonomik değişkenlerin kadına yönelik şiddet tutumlarını olumsuz etkilemesi beklenirken farklı ekonomik giderlere sahip bireylerin tutumlarının benzer ortalamalarda olması eğitim düzeyinin ekonomi değişkenini de olumlu yönde etkilediği biçiminde yorumlanmaktadır.

\section{Sosyal Öğrenci Topluluklarına Üyelik Değișkeni Açısından KYŞTÖ Ortalama Puanlarına Illişkin Bulgular}

Öğrenci toplulukları özellikle üniversiteye yeni başlayan bireylerin sosyalleşmesi ve üniversite kültürünü edinmelerinde önemli roller üstlenmektedir. Bireylerin üniversiteye girene kadar sahip oldukları tutumlar bu toplulukların etkisiyle pekiştirilebilir ya da değişebilir. Bu açıdan öğretmen adaylarının tutumlarına bir etkisinin olup olmadığı belirlenmeye çalışılmıştır. Katılımcıların herhangi bir sosyal öğrenci topluluğuna üye olup olmama durumuna açısından ölçekten aldıkları puanların farklılaşıp farklılaşmadığına ilişkin t-testi sonuçları Tablo 16'da sunulmuştur.

Tablo 16. Katılımcıların KYŞÖ Puanlarının Herhangi Bir Sosyal Öğrenci Topluluğuna Üye Olup Olmama Durumuna Göre t-Testi Sonuçları

\begin{tabular}{ccccccc}
\hline Topluluk Üyeliği & $\mathbf{N}$ & $\overline{\mathbf{X}}$ & $\mathbf{S}$ & $\mathbf{t}$ & $\mathbf{S d}$ & $\mathbf{p}$ \\
\hline Evet & 155 & 78,8903 & 11,61368 &,- 373 & 935 &, 709 \\
\hline Hayır & 782 & 79,2251 & 9,89318 & & & \\
\hline
\end{tabular}

Katılımcıların çoğunluğunun herhangi bir öğrenci topluluğuna üye olmadıkları görülmektedir. Analiz sonuçlarına göre, katılımcıların ölçekten aldıkları ortalama puanlar herhangi bir sosyal öğrenci topluluğuna üye olup olmama durumuna göre anlamlı bir farkll1ık göstermemektedir [ $\mathrm{t}(935)=0,373, \mathrm{p}>.05]$. Bu bulgu, bir topluluğa üye olmanın kadına yönelik şiddete dönük tutumda anlamlı bir fark yaratmadığı şeklinde yorumlanabilir.

\section{Romantik Ilișki Yașamıș Olma Değișkeni Açısından KYŞTÖ Ortalama Puanlarına İlișkin Bulgular}

Bireylerin önceki yaşantıları tutumları üzerinde önemli etkilere sahiptir. Bireylerin karşı cinsle yaşadıkları ilişkiler onların karşı cinse yönelik davranışlarını da etkileyebileceği öngörülmektedir. $\mathrm{Bu}$ önermeden yola çıkarak daha önce yaşanmış romantik ilişkilerin kadına yönelik şiddet tutumuna etkisine incelenmesi düşünülmüştür. Katılımcıların daha önce bir romantik ilişkilerinin olup olmama durumu açısından ölçekten aldıkları puanların farklılaşıp farklılaşmadığına ilişkin t-testi sonuçları Tablo 17'de sunulmuştur.

Tablo 17. Katılımcıların KYŞÖ Puanlarının Daha Önce Bir Romantik Illişkilerinin Olup Olmama Durumuna Göre t-Testi Sonuçları

\begin{tabular}{ccccccc}
\hline Romantik İlişki & $\mathbf{N}$ & $\overline{\mathbf{X}}$ & $\mathbf{S}$ & $\mathbf{t}$ & $\mathbf{S d}$ & $\mathbf{p}$ \\
\hline Evet & 533 & 80,3227 & 9,90903 & 4,010 & 935 &, 000 \\
\hline Hayır & 404 & 77,6485 & 10,37104 & & & \\
\hline
\end{tabular}

Analiz sonuçlarına göre, katılımcıların ölçekten aldıkları ortalama puanlar daha önce bir romantik ilişkilerinin olup olmama durumuna göre anlamlı bir farklılık göstermektedir $[\mathrm{t}(935)=4,010, \mathrm{p}<.001]$. Daha önce romantik ilişkisi olan katılımcıların ölçekten aldıkları ortalama puan $(\overline{\mathbf{X}}=80,32)$, ilişkisi olmayan katılımcıların ölçekten aldıkları ortalama puandan $(\overline{\mathbf{X}}=77,64)$ daha yükssektir. Bu bulgu, romantik ilişki yaşamış olan katılımcıların kadına yönelik şiddet tutumlarının diğer katılımcılara göre anlamlı biçimde daha olumlu olduğuna işaret etmektedir. 
Katılımcıların şu anda bir romantik ilişkilerinin olup olmama durumu açısından ölçekten aldıkları puanların farklılaşıp farklılaşmadığına ilişkin t-testi sonuçları Tablo 18'de sunulmuştur.

Tablo 18. Katılımcıların KYŞÖ Puanlarının Şu Anda Bir Romantik İlişkilerinin Olup Olmama Durumuna Göre T-Testi Sonuçları

\begin{tabular}{ccccccc}
\hline Romantik İlişki & $\mathbf{N}$ & $\overline{\mathbf{X}}$ & $\mathbf{S}$ & $\mathbf{t}$ & $\mathbf{S d}$ & $\mathbf{p}$ \\
\hline Evet & 271 & 80,6863 & 9,56272 & 2,917 & 935 &, 004 \\
\hline Hayır & 666 & 78,5526 & 10,38063 & & & \\
\hline
\end{tabular}

Analiz sonuçlarına göre, katılımcıların ölçekten aldıkları ortalama puanlar şu anda bir romantik ilişkilerinin olup olmama durumuna göre anlamlı bir farklılık göstermektedir $[\mathrm{t}(935)=2,92, \underline{\mathrm{p}<.001]}$. Şu anda romantik ilişkisi olan katılımcıların ölçekten aldıkları ortalama puan $(\overline{\mathbf{X}}=80,69)$, olmayan katılımcıların ölçekten aldıkları ortalama puandan $(\bar{X}=78,55)$ daha yüksektir. Bu bulgu, şu anda bir romantik ilişkisi olan katılımcıların kadına yönelik şiddete dönük tutumlarının diğer katılımcılara göre anlamlı biçimde daha olumlu olduğuna işaret etmektedir. Kadına yönelik şiddetin failinin, tüm dünyada olduğu gibi Türkiye'de de genellikle kadının eşi ya da yakın ilişki yaşadığı bir erkek olduğu bilinmektedir. Güler, Tel ve Tuncay (2005) kadınların \%40,7'sinin aile içi şiddete maruz kaldıklarını ve şiddet uygulayanların da \%91'inin eşleri olduğu sonucuna ulaşmıştır. $\mathrm{Bu}$ açıdan romantik bir ilişki içerisinde olan bireylerin şiddete maruz kalma olasılıkları yüksektir. Ancak kadına yönelik şiddet tutum puanlarının yüksek olmasının nedenleri arasında eğitim düzeyi başta olmak üzere farklı bir çok değişkenin de (örneğin cinsiyet, yaş, ilişkinin süresi, vb.) etkisinin olabileceğini düşündürmektedir.

\section{Aile Içi Şiddete Tanık Olma Değișkeni Açısından KYŞTÖ Ortalama Puanlarına ilișkin Bulgular}

Katılımcıların aile içi şiddete tanık olup olmama durumu açısından ölçekten aldıkları puanların farklılaşıp farklılaşmadığına ilişkin t-testi sonuçları Tablo 19'da sunulmuştur.

Tablo 19. Katıımcıların KYŞÖ Puanlarının Aile içi şiddete tanık olup olmama durumuna Göre tTesti Sonuçları

\begin{tabular}{ccccccc}
\hline $\begin{array}{c}\text { Aile içi } \\
\text { Şiddete Tanık } \\
\text { Olma Durumu }\end{array}$ & $\mathbf{N}$ & $\overline{\mathbf{X}}$ & $\mathbf{S}$ & $\mathbf{t}$ & Sd & $\mathbf{p}$ \\
\hline Evet & 386 & 79,3135 & 9,88388 &, 361 & 935 &, 718 \\
\hline Hayır & 551 & 79,0690 & 10,40991 & & & \\
\hline
\end{tabular}

Analiz sonuçlarına göre, katılımcıların ölçekten aldıkları ortalama puanlar aile içi şiddete tanık olup olmama durumuna göre anlamlı bir farklılık göstermemektedir $[\mathrm{t}(935)=0,361$, $\mathrm{p}>$.05]. Bu bulgu, aile içi şiddete tanık olup olmanın kadına yönelik şiddete dönük tutumda anlamlı bir fark yaratmadığı şeklinde yorumlanabilir. Alan yazında aile içi şiddete tanık olan bireylerin şiddet uygulama olasıllğının daha yüksek olabileceği iddia edilmektedir. Ancak yukarıdaki bulgu bu iddia ile ters düşmektedir. Aile içi şiddete tanık olmuş katılımcıların kadına yönelik şiddet tutum puanlarının daha yüksek olması alan yazındaki bu bilgiyi desteklememektedir. 


\section{Tartıșma ve Sonuç}

Araştırmada yurttaşlık eğitimi sorumluluğunu üstlenecek olan sosyal bilgiler branşı öğretmen adaylarının kadına yönelik şiddet tutumlarını etkileyen değişkenler belirlenmeye çalışılmıştır. Sonuç olarak; öğretmen adaylarının kadına yönelik şiddet tutumlarının, cinsiyet, öğrenim görülen üniversite, erkek kardeş sayısı, anne-baba eğitim düzeyi, romantik bir ilişki yaşamış olma ve yaşıyor olma durumuna göre anlamlı düzeyde farklılaştı̆̆ belirlenmiştir. Ancak anlamlı fark bulunmasına rağmen tutum puanı ortalamalarının biribirine yakın olduğu da görülmektedir.

Araşıırma kapsamında incelenen sınıf düzeyi, kız kardeş sayısı, aylık ortalama gider, bir öğrenci topluluğuna üye olma ve aile içi şiddete tanık olma değişkenlerinin, öğretmen adaylarının kadına yönelik şiddet tutumları açısından anlamlı bir fark yaratmadığı sonucuna ulaşıılmıştır.

DSÖ (2017) eğitim düzeyi düşük, annelerine yönelik şiddete tanık olmuş ve alkol kullanan erkeklerin kadına yönelik şiddet gösterme olasılıkları ile eğitim düzeyi düşük, çocukluk döneminde şiddete maruz kalmış ve erkek üstünlüğünü kabul eden kadınların şiddete uğrama olasılıklarının yüksek olduğunu ifade etmiştir. Bu belirleme ile eğitim düzeyinin kadına yönelik şiddet üzerindeki etkisi açısından elde edilen bulgular benzerlik göstermektedir.

Araştırma sonuçları kadına yönelik şiddetin önlenmesinde en önemli aracın da eğitim olduğunu göstermektedir. Alan yazında yer alan araştırma sonuçları bireylerin kadına yönelik şiddet tutumlarının ekonomik düzeyden ve aile içi şiddete maruz kalma ya da tanık olma durumundan etkilendiğini göstermektedir. Ancak bu çalışmada hem ekonomik düzey hem de aile içi şiddete maruz kalma durumları açısından, katılımcıların tutum puanları arasında anlamlı farklar ile karşılaşılmamıştır. Bu durumun katılımcıların üniversitede öğrenim gören öğretmen adayları olmasından kaynakladığı düşünülmektedir. Ancak katılımcıların, tutum maddelerine olması gereken yanıtları verirken, gerçek yaşamlarında bu yanıtlara uygun davranışlar göstermeyebilecekleri de göz önünde bulundurulmalıdır.

Kadına yönelik şiddet dünya genelinde bir sorun olmaya devam etmektedir. Birleşmiş Milletler Kadın Platformunun güncel web sitesinde 2013 yılına dayandırılan verilere göre; dünya genelinde kadınların $\% 35$ 'i eşleri ya da eşleri olmayan erkekler tarafindan psikolojik ve cinsel şiddete maruz kalmışlardır (UNWOMEN, 2020). Avrupa genelinde ise 15 yaşından itibaren kadınların fiziksel ya da cinsel şiddet yaşama oranları \%33'tür ve bu oran Danimarka'da \%52'ye, Finlandiya'da \%47'e ulaşmaktadır (FRA, 2012).

Sayılan (2014) eğitim sisteminin tüm düzeylerinde küresel toplumsal cinsiyet eşitliği politikalarıyla uyumlu görünmesine rağmen eşitsizlik ve ayrımcılık barındırdığını belirtmektedir. Kadına yönelik şiddetin önlenmesinde önemli bir araç işlevi görebilecek olan eğitim siteminin yapısında ve içeriğinde mevcut olan eşitsizlikler ve bu eşitsizliklerin giderilmesi için yapılması gerekenler konusunda hükümetlerin gerekli adımları atmadıkları, dolaylı olarak kadına yönelik şiddeti engellemeye ilişkin çalışmaların bir sonuca ulaşamadığı düşünülmektedir.

Araştırma sonuçları arasında en dikkat çekici durum üniversitede toplumsal cinsiyet konulu eğitimler almış olan öğrencilerin kadına yönelik şiddet bağlamında duyarlılık ve farkındalık kazanmış olmalarıdır. Toplumsal cinsiyet eğitiminin kazanımları yalnızca kavramsal ve kuramsal düzlemde kalmamakta, katılımcıların kendi yaşam deneyimleriyle anlamlandırdıkları farklı bir bilgi türü ve gündelik yaşamda devam eden bir farkındalık ve duyarlılık yaratmaktadır (Williams, Seed ve Mwau, 1994). Toplumsal cinsiyet eşitliğine odaklanan ve öğretmen adaylarıyla yürütülen bir lisans dersi kapsamında gerçekleştirilen bir araştırmada da katılımcıların geleneksel ataerkil değer yargılarını sorgulamaya başladıkları, kendi yaşamlarından başlayan bir değişim/dönüşüm motivasyonu kazandıkları görülmüş̧ür (Esen, 2013). 
Kadına yönelik şiddetin engellenmesinde kullanılabilecek en önemli aracın eğitim olduğu görülmektedir. $\mathrm{Bu}$ kapsamda gerek bireyleri gerekse anne ve babalarını kapsayacak eğitimlerin gerçekleştirilmesi önerilmektedir. Bu eğitimlerin yanı sıra formal eğitim ortamları dışında kullanılabilecek öğretim materyallerinin geliştirilmesi ve medya aracılığıyla geniş kitlelere ulaştırılması sağlanmalıdır. Ayrıca toplumsal cinsiyet eşitliğini geliştirmeye yönelik üniversite düzeyinde derslerin tüm fakültelerin programlarında yer alması sağlanabilir.

\section{Araștırmanın Sınırlılıkları ve Gelecek Araştırmalar}

Araştırmanın başlıca sınırlılıkları şu şekildedir:

- Türkiye'de kadına yönelik şiddetle ilgili resmi veriler güncel değildir.

- Kadına yönelik şiddetle ilgili alanyazın sınırıdır.

- Araştırma 2017-2018 eğitim öğretim yılındaki altı farklı kamu üniversitesinin sosyal bilgiler öğretmenliği bölümünde okuyan öğrencilerle sınırlıdır.

- Araştırma Kadına Yönelik Şiddet Tutum Ölçeği aracılığıyla elde edilen verilerle sinirlidir.

Gelecekte bu konuda yapılacak yapılacak çalışmalar diğer öğretmenlik branşlarını ya da farklı fakültelerde öğrenim gören üniversite öğrencilerini de kapsayacak biçimde gerçekleştirilebilir. Ayrıca kadına yönelik şiddet tutumlarını etkileyebilecek başka değişkenlerin tutumlar üzerindeki etkilerine bakılabilir.

\section{Yazar Katkıları}

$\mathrm{Bu}$ araştırma Ankara Üniversitesi Eğitim Bilimleri Fakültesi Sosyal Bilgiler Eğitimi anabilim dalında Doç. Dr. Yasemin Esen'in danışmanlığında Dr. Öğr. Üyesi Serkan Keleşoğlu'nun gerçekleştirmiş oldukları bir yüksek lisans tezinden üretilmiştir. Araştırmanın tüm süreçlerinde araştırmacıların katkısı bulunmaktadır. Tüm yazarlar makalenin yayınlanmış halini okudular ve Kabul ettiler.

\section{Yayın Etiği}

Araştırma ve Yayın Etiği'ne uyuldu

\section{ORCID}

Serkan Keleşoğlu (10) https://orcid.org/0000-0002-1208-6919

Yasemin Esen (1) https://orcid.org/0000-0003-3966-6726

Kaynakça

Altınay, A. G. ve Arat, Y. (2007). Türkiye'de Kadına Yönelik Şiddet. http://www.kadinayoneliksiddet.org/ Baran, A. G., Kütük, B. Ş., \& Maybek, D. (2012). Kadınların Eşleri Tarafından Gördükleri Şiddeti Meşrulaştırmaları Üzerinde Kamusal Alanın Etkisi. Sosyal ve Beşeri Bilimler Dergisi, 4(2), 41-50.

Büyüköztürk, Ş., Çakmak, E. K., Akgün, Ö. E., Karadeniz, Ş. \& Demirel, F. (2008). Bilimsel araştırma yöntemleri. Ankara: Pegem.

BM Kadınlara Karşı Şiddetin Ortadan Kaldırılması Bildirgesi.

http://www.unicankara.org.tr/doc_pdf/metin139.pdf_20.5.2018 tarihinde indirilmiştir. 
CEDAW Sözleşmesi. http://www.kadininstatusu.gov.tr/tr/html/19131/Uluslararasi-Belgeler adresinden

21.9.2018 tarihinde indirilmiştir.

CEDAW Komitesi'nin 19 no.lu genel tavsiyesi

http://www.un.org/womenwatch/daw/cedaw/recommendations/recomm.htm\#recom19) adresinden

21.9.2018 tarihinde indirilmiştir.

CEDAW-Tavsiye Kararları (General Recommendations)

http://www2.ohchr.org/english/bodies/cedaw/comments.htm. adresinden 6.6.2017 tarihinden indirilmiştir.

Çakır, Ö., Harcar, T., Sürgevil, O. \& Budak, G. (2014). Kadına yönelik şiddet ve Türkiye'de kadına yönelik şiddetin durumu. Toplum ve Demokrasi Dergisi, 2(4), 51-70.

Çalışkan, H., \& Çevik, E. İ. (2018). Kadına Yönelik Şiddetin Belirleyicileri: Türkiye Örneği. Balkan Sosyal Bilimler Dergisi, 7(14), 218-233.

Çötok Akıncı, N. (2015). Toplumsal cinsiyet rolü dâhilinde kadına şiddet olgusuna karşı kadın algısı. International Journal of Social Sciences and Eduaction Research 1(3), s.938-952.

Esen, Y. (2013). Hizmet Öncesi Öğretmen Eğitiminde Toplumsal Cinsiyet Duyarlılığını Geliştirme Amaçlı Bir Çalışma. Ĕgitim ve Bilim, 38(169), 280-295.

FRA (2012). https://fra.europa.eu/en/publications-and-resources/data-and-maps/survey-data-explorerviolence-against-women-survey 30.6.2020 tarihinde indirilmiştir.

Güler, N., Tel, H. ve Özkan Tuncay, F. (2005). Kadının aile içinde yaşanan şiddete bakışı. Cumhuriyet Üniversitesi Tıp Fakültesi Dergisi 27 (2), 51-56.

Kadınlara Yönelik Şiddet ve Aile İçi Şiddetin Önlenmesi ve Bunlarla Mücadeleye İlişkin Avrupa Konseyi

Sözleşmesi. http://www.resmigazete.gov.tr/eskiler/2012/03/20120308M1-1.pdf. Adresinden 7.6.2017

tarihinde indirilmiştir.

Kalaycı, Ş. (2006). SPSS uygulamalı ve çok değişkenli istatistiksel teknikleri. Ankara: Asil.

Karal, D., \& Aydemir, E. (2012). Violence against women in Turkey. Ankara Uluslararası Stratejik Araştırmalar Kurumu Sosyal Araştırmalar Merkezi.

Karasar, N. (2004). Bilimsel araştırma yöntemleri. Ankara: Nobel.

Köknel, Ö. (2013). Şiddet Dili. İstanbul: Remzi

Köşgeroğlu, N., Çulha, İ., ve Öz, Z. (2015). Şiddet karşısında kadınların davranışlarının incelenmesi. Akademik Sosyal Araştırmalar Dergisi 3, s. 342-350.

KSGM (2006). Kadına yönelik aile içi şiddetle mücadele ulusal eylem planı. Ankara.

KSGM (2012). Kadına yönelik şiddetle mücadele eylem planı. http://kadininstatusu.aile.gov.tr/data/54296cb3369dc32358ee2c51/Kad\%C4\%B1na\%20Y\%C3\%B6ne lik\%20Aile $\% 20 \% \mathrm{C} 4 \% \mathrm{~B} 0 \% \mathrm{C} 3 \%$ A7i $\% 20 \% \mathrm{C} 5 \% 9$ Eiddet $\% 20$ Ulusal $\% 20$ Eylem $\% 20 \mathrm{Plan} \% \mathrm{C} 4 \% \mathrm{~B} 1 \% 2$ 0(2012_2015).pdf adresinden 20.5.2017 tarihinde indirilmiştir.

KSGM (2016). Kadına yönelik şiddetle mücadele eylem planı. http://kadininstatusu.aile.gov.tr/data/585d231c369dc55714513399/Kad\%C4\%B1na\%20Y\%C3\%B6n elik\%20\%C5\%9Eiddetle\%20M\%C3\%BCcadele\%20Ulusal\%20Eylem\%20Plan\%C4\%B1\%2020162020.pdf adresinden 20.5.2017 tarihinde indirilmiştir.

MEB (2014). 2013-2014 Örgün eğitim verileri. http://sgb.meb.gov.tr/www/milli-egitim-istatistikleriorgun-egitim-2013-2014/icerik/95 09.5.2017 tarihinde yararlanılmıștır.

Page, A. Z., \& İnce, M. (2008). Aile içi şiddet konusunda bir derleme. Türk Psikoloji Yazıları, 11(22), 8194.

Sayılan, F. (2014). Toplumsal cinsiyet ve eğitim olanaklar ve sinırlar. Ankara: Dipnot.

Sencer, M., (1989). Toplum bilimlerinde yöntem. İstanbul: Beta.

Sümer, N. (2000). Yapısal eşitlik modelleri: Temel kavramlar ve örnek uygulamalar. Türk Psikoloji Yazllarl, 3(6), 49-74.

Şenol, D. ve Yıldız S. (2013). Kadına Yönelik Şiddet Algısı. Ankara: Mutlu Çocuklar Derneği.

Şimşek, Ö. F. (2007). Yapısal eşitlik modellemesine giriş: Temel ilkeler ve LISREL uygulamaları. Ankara: Ekinoks.

WHO, (2017). https://www.who.int/news-room/fact-sheets/detail/violence-against-women adresinden alınmıştır.

Williams, S, Seed, J. ve Mwau, A. (1994). The Oxfam gender training manual. Oxford: Oxfam.

UNICEF (2003). Eğitimin Toplumsal Cinsiyet Açısından İncelenmesi: Türkiye Raporu. Ankara:

UNICEF, [Online]: http://www.unicef.org/turkey/pdf/_ge21.pdf adresinden 10 Temmuz 2009 tarihinde

indirilmiştir.

UNWOMEN (2020), https://unstats.un.org/unsd/gender/vaw/ 30.6.2020 tarihinde indirilmiştir.

Usta, G., Keleşoğlu, S. ve Esen, Y. (2015). "A Scale of attitudes towards violence against women: validity and reliability testing" presented in The International Congress on Education for the Future: Issues and Challenges, Ankara.

Yanık, A., Hanbaba, Z., Soygür, S., Ayaltı, B., \& Doğan, M. (2014). Kadına Yönelik Şiddet Davranışlarının Değerlendirilmesi: Türkiye'den Kanıt. Electronic Journal of Vocational Colleges, Aralık, 4, 104-11. 


\section{Extended Abstract}

\section{Introduction}

Violence against women remains one of the most common global problems. Turkey is unfortunately the case has become a country that confront every day with increasing rates of female murders, defined as the end point of the range of violence. Women, perhaps more than any other, worry about their right to life. Violence and Domestic Prevention of Violence Against Women which was signed on Turkey in 2011 and the 6284 numbered Protection of the Family and regulations Law on Prevention of Violence Against Women, combating violence against women has brought positive changes, though legal. It is a fact that regulations have made limited progress in preventing violence against women. In other words, it is clear that legal regulations alone are not sufficient in combating violence against women, and that other social institutions should take responsibility and initiative in this struggle. Accepting violence against women as a human rights issue requires that this issue be addressed with a holistic approach and with the cooperation of all sectors (private and public). Coordination between stakeholders within the framework of such an approach and the main institutions that provide cooperation Family, Labor and Social Services Combating Violence Project for the Ministry of Women's National Action Plans (20072010 and 2012-2015), Turkey in reaching the targets set in the framework of international commitments puts responsibility on universities and faculties that train teachers. This study, carried out within the framework of this responsibility, aims to determine pre-service teachers' attitudes towards violence against women and the variables that affect these attitudes as a profession that can undertake one of the important duties in preventing violence against women.

In addition to the steps taken in the legal field to solve the problem of violence against women, action plans are of great importance in terms of defining other institutions and organizations as stakeholders in solving the problem. Turkey prepared by KSGM 20072010, training in the target for the prevention of violence against women in the 2012-2015 and 2016-2020 Action Plan constitutes an important dimension. Schools have an important role in preventing violence that children may be victims, perpetrators or witnesses in all areas of social life, inside or outside the family. Although there are stimuli to raise awareness and raise awareness in curricula, textbooks and media, teachers can be role models in providing permanent awareness in the lives of students at primary and secondary school level. It is not realistic to expect the teacher as an individual not to carry his / her attitudes and behaviors into the classroom. Teachers can be a positive or negative example in students' interpretation of violence with their words and behaviors they say consciously or unconsciously. In this context, teachers should receive awareness and awareness training on gender equality in the pre-service period. Evaluating the effect of the training that teachers and pre-service teachers' will receive and determining the factors affecting their attitudes will provide helpful data in planning the education they will receive. It is important for teachers to determine their attitudes towards violence against women in the pre-service period and to gain awareness with the necessary training based on this determination. It is thought that this study will contribute to the realization of the preservice education more effectively by determining the variables that affect the pre-service teachers' attitudes towards violence against women. In particular, social studies teachers who take responsibility for citizenship education differ from other branches in this respect. There are many different variables that affect violence. The most important of these variables are cultural transfer, economic problems, education received and family socialization practices. It is important to determine which of these variables affect social studies pre-service teachers' attitudes towards violence against women. Although there have been efforts to raise awareness on gender equality in the national and international literature in recent years, the number of studies on violence against women is not sufficient. 
Most of the studies conducted are aimed at determining the violence situation of women. It is thought that this research will be important in terms of providing data for future studies.

\section{Method}

This research has been modeled as a descriptive research in order to determine the attitudes of social studies pre-service teachers' to violence against women. Within the scope of the research, it was tried to determine the attitude levels of social studies pre-service teachers' to violence against women. Participants contributing to the research are social studies preservice teachers' studying at six different state universities. The reason why the study group was chosen only from the social studies branch is that the social studies discipline is directly responsible for teaching rights and rights within the scope of citizenship education. Since a sensitive issue such as violence against women was studied, various difficulties were experienced in reaching the universe and a sample that could represent the universe. Therefore, a working group was formed. The participants of the study group in which measurement tools were applied were selected by using the appropriate case sampling technique, taking into account the status of "being a pre-service teachers' from the social studies branch". The data in the study were collected using the "Violence Against Women Attitude Scale" (VAWAS) developed by Usta, Keleşoğlu and Esen (2017). SPSS 16.00 (Statistics Program for Social Sciences) and LISREL package programs were used to analyze the data from the research. Frequency and percentage distribution in the analysis of demographic characteristics of the participants; T-test for unrelated samples and one-way analysis of variance (ANOVA) for unrelated samples were used to determine whether violence against women differs according to demographic variables. In order to determine the differences between groups in the analysis of variance, Scheffe test was preferred because of its low permeability from the multi-comparison tests. In the analysis of the data, the confidence interval was taken as .05 .

\section{Purpose}

The aim of this study is to determine whether there is a significant difference between different variables and the attitudes of violence against women of pre-service teachers studying in social studies teaching program. For this purpose, answers to the following questions were sought:

Social studies pre-service teachers' scores of violence against women;

1. Does it differ according to the gender variable?

2. Does their education differ according to the variable of the university they attend?

3. Does their education differ according to the grade level variable?

4. Does the number of sisters differ according to the variable?

5. Does the number of brothers differ according to the variable?

6. Does the mother differ according to the educational level variable?

7. Does the father differ according to the educational level variable?

8. Does it differ according to the variable of being a member of a student community?

9. Does it differ according to the variable of having a romantic relationship?

10. Does it differ according to the variable of maintaining a romantic relationship?

11. Does it differ according to the variable of witnessing domestic violence? 


\section{Findings}

In terms of gender variable, there is a significant difference in favor of women between the Violence Against Women Attitude Scores of the participants. While the mean scores of female pre-service teachers are 82.51 , the average score of male pre-service teacher is 74.61 .

There is a significant difference between pre-service teachers' scores in terms of universities where they continue their education. The average score of the pre-service teachers' studying at the number one university is 84.77 , which is higher than the average of other universities.

There is no significant difference between pre-service teachers' VAWAS scores in terms of grade level variable, the number of sisters, monthly average expenditure, being a member of a social student community and witnessing domestic violence.

There is a significant difference between pre-service teachers' VAWAS scores in terms of the variable number of brothers owned. While the average of the pre-service teachers' without brothers is 80.98 , the average of the pre-service teachers' with three brothers is 76.49. This difference between the averages is significant.

There is a significant difference between pre-service teachers' VAWAS scores in terms of the mothers' and fathers' education level variable. The scores of the pre-service teachers whose mothers were primary school graduates were significantly lower than those of the pre-service teachers whose mothers were middle school, high school and college graduates. The average of the pre-service teachers whose fathers were primary school graduates was significantly lower than the scores of the prospective teachers whose fathers were college graduates.

There is a significant difference between pre-service teachers' VAWAS scores in terms of the variable of having a romantic relationship before and having a romantic relationship now This difference favors those who have a romantic relationship.

\section{Discussion and Conclusion}

In the study, it was tried to determine the variables that affect the attitudes of violence against women of social studies pre-service teachers who will undertake the responsibility of citizenship education. As a result; It was determined that there was a significant difference between pre-service teachers' attitude towards violence against women and the variables of gender, university attended, number of brothers, education level of parents, having a romantic relationship and being alive. However, although there is a significant difference, it is also seen that the mean attitude score is close to each other.

It was concluded that the variables of class level, number of sisters, average monthly expenses, being a member of a student community and witnessing domestic violence did not make a significant difference in terms of pre-service teachers' attitudes towards violence against women.

WHO (2017) stated that men who have a low education level, witnessed violence against their mothers, and alcohol-consuming men are likely to commit violence against women and have a low educational level, women who have been subjected to violence during childhood and who accept male supremacy are more likely to experience violence. This determination and the findings obtained in terms of the effect of education level on violence against women are similar.

Research results show that the most important tool in preventing violence against women is education. The research results in the literature show that individuals' attitudes towards 
violence against women are affected by the economic level of being exposed to and witnessing domestic violence. However, in this study, no significant differences were encountered between the attitude scores of the participants in terms of both the economic level and the exposure to domestic violence. It is thought that this situation is due to the fact that the participants are pre-service teachers studying at the university. However, it should be taken into account that the participants may not behave in accordance with the answers in their real lives while giving the correct answers to the attitude items.

Violence against women continues to be a worldwide problem. According to the data based on 2013 on the current website of the United Nations Women's Platform; 35\% of women worldwide have been subjected to psychological and sexual violence by men who do not have a husband or wife (UNWOMEN, 2020). Unfortunately, this data is similar in European countries, which are called developed countries. Since the age of 15, the rate of women experiencing physical or sexual violence across Europe is $33 \%$, and this rate reaches 52\% in Denmark and 47\% in Finland (FRA, 2012).

Sayılan (2014) states that although it seems compatible with global gender equality policies at all levels of the education system, it contains inequality and discrimination. It is believed that the inequalities in the structure and content of the education system, which can serve as an important tool in the prevention of violence against women, and that the governments did not take the necessary steps to eliminate these inequalities and indirectly did not come to a conclusion from their efforts to prevent violence against women.

The most striking situation among the results of the study is that the students who have received university education on gender issues have gained sensitivity and awareness in the context of violence against women.

\section{Implication and Suggestions}

It is seen that the most important tool that can be used to prevent violence against women is education. In this context, it is recommended to carry out trainings that will cover both individuals and their mothers and fathers. In addition to these trainings, it should be ensured that teaching materials that can be used outside of formal education environments are developed and delivered to large masses through the media. In addition, it can be ensured that university-level courses aimed at improving gender equality are included in the programs of all faculties.

\section{Research Limitations and Future Research}

The main limitations of the research are as follows:

- The existing data on violence against women are not up to date,

- Limited literature on violence against women,

- The study is limited to students studying in the social studies teaching department of six different public universities in the 2017-2018 academic year,

- It is limited to the data obtained in the Violence Against Women Attitude Scale.

Future studies on this subject can be carried out in a way that includes other teaching branches or university students studying in different faculties. In addition, the effects of other variables that can affect attitudes of violence against women on attitudes can be examined. 
This research, under the supervision of Dr. Yasemin Esen, was conducted by Dr. Serkan Keleşoğlu, It was produced from a master thesis carried out by its member, Researchers contribute to all processes of the research. All authors have read the published version of the article and accepted. Authorship should be limited to those who contributed significantly to the work.

\section{Publication Ethics}

Research and Publication Ethics was complied 